\title{
Recent Advances on Quinazoline Derivatives: A Potential Bioactive Scaffold in Medicinal Chemistry
}

\author{
Ram Karan ${ }^{1}$, Pooja Agarwal ${ }^{1, *,+}$, Mukty Sinha $^{2}$ and Neelima Mahato ${ }^{3, *,+}+\mathbb{C}$ \\ 1 Division of Chemistry, School of Basic and Applied Sciences, Galgotias University, Yamuna Expressway, \\ Greater Noida 203201, India; ramkaran.ra@gmail.com \\ 2 Department of Medical Devices, National Institute of Pharmaceutical Education and Research, Ahmedabad, \\ Palej, Gandhinagar 382355, India; muktys@gmail.com \\ 3 School of Chemical Engineering, Yeungnam University, Gyeongsan 38541, Korea \\ * Correspondence: pooja.agarwal@galgotiasuniversity.edu.in (P.A.); neelapchem@gmail.com (N.M.); \\ Tel.: +91-9899656455 (P.A.); +82-010-2798-8476 (N.M.) \\ + Contributed equally as first author.
}

\section{check for} updates

Citation: Karan, R.; Agarwal, P.; Sinha, M.; Mahato, N. Recent Advances on Quinazoline Derivatives: A Potential Bioactive Scaffold in Medicinal Chemistry. ChemEngineering 2021, 5, 73. https://doi.org/10.3390/ chemengineering5040073

Academic Editors: Alírio

E. Rodrigues, Brian Trewyn, José P. Coelho and Andrew S. Paluch

Received: 29 June 2021

Accepted: 27 September 2021

Published: 26 October 2021

Publisher's Note: MDPI stays neutral with regard to jurisdictional claims in published maps and institutional affiliations.

Copyright: (c) 2021 by the authors. Licensee MDPI, Basel, Switzerland. This article is an open access article distributed under the terms and conditions of the Creative Commons Attribution (CC BY) license (https:/ / creativecommons.org/licenses/by/ $4.0 /)$.

\begin{abstract}
This paper intended to explore and discover recent therapeutic agents in the area of medicinal chemistry for the treatment of various diseases. Heterocyclic compounds represent an important group of biologically active compounds. In the last few years, heterocyclic compounds having quinazoline moiety have drawn immense attention owing to their significant biological activities. A diverse range of molecules having quinazoline moiety are reported to show a broad range of medicinal activities like antifungal, antiviral, antidiabetic, anticancer, anti-inflammatory, antibacterial, antioxidant and other activities. This study accelerates the designing process to generate a greater number of biologically active candidates.
\end{abstract}

Keywords: quinazoline; antifungal; anticancer; anti-inflammatory; antibacterial; antioxidant

\section{Introduction}

Heterocyclic rings containing nitrogen and sulfur are of much intention as they are therapeutically and pharmacologically more active. These compounds are the building blocks of many pharmaceutical products. Among all heterocyclic moieties, quinazoline has been taken for this review, as quinazoline has a very broad spectrum of pharmacological activities with minimum side effects [1]. Quinazoline is a well known heterocyclic compound having the chemical formula $\mathrm{C}_{8} \mathrm{H}_{6} \mathrm{~N}_{2}$. Quinazoline is a light yellow crystalline solid and is also known as 1,3-diazanaphthalene, which comprises one benzene and one pyrimidine ring. Synthesis of quinazoline was first reported through decarboxylation of 2-carboxy derivative by August Bischler and Lang in 1895 [2]. Anthranilic acid on treatment with amide resulted in 4-oxo-3,4-dihydroquinazolies by Niementowski synthesis [3]. Other isomers of quinazoline are quinoaxoline, cinnoline and phthalizine [4]. Quinazolines are also the building blocks of more than 200 natural alkaloids isolated from plants, microorganisms and animals [5,6]. Vasicine $( \pm)$ (peganine) was the first known quinazoline alkaloid which was isolated from Adhatoda vasica in 1888. It is highly effective against bronchodilator activity [7].

Quinazolinone is one of the derivatives of quinazoline which is active like quinazoline [8]. Based on the substitution pattern, quinazolinones are further divided into subcategories such as 2-quinazolinone (a) and 4-quinazolinone (b) as shown in Figure 1 [9].

Thus, quinazoline is a structure of great interest in the area of pharmaceutical chemistry, featuring in various drugs, clinical candidates and bioactive molecules. The focus of this review is on potential biological activity of quinazoline derivatives. This review article will be advantageous in providing information regarding the latest developments on quinazoline analogs having completely different pharmacological activities like antitumor, antimicrobial, antimalarial, antiviral and antidiabetic, etc. This review will also be 
stimulating for the researchers to design, synthesize and enhance the potentiality of vital medicine having quinazoline moieties for the treatment of assorted diseases in the future.<smiles>O=c1[nH]cnc2ccccc12</smiles>

(a)<smiles>O=c1ncc2ccccc2[nH]1</smiles>

(b)

Figure 1. 2-quinazolinone (a) and 4-quinazolinone (b).

\section{Synthesis Routes of Quinazoline}

There are several reported methods to synthesize quinazoline moiety.

(i) Niementowski quinazoline synthesis: Anthranilic acid when treated with formamide at higher temperature resulted 3,4 dihydro-4-oxaquinazoline (Figure 2) [10].

(ii) Grimmel, Guinther and Morgan's synthesis: The 2-acetamidobenzoic acid reacts with an amine in the presence of phosphorous trichloride gave 2-methyl-3-phenylquinazolin4(3H)-one (Figure 3) [10].

(iii) Synthesis of quinazolin-4(3H)-one from Isotoic anhydride: The Isotoic acid anhydride reacts with amine followed by refluxing with ethyl orthoformate resulted in dihydro4-oxaquinazolines (Figure 4) [1].

(iv) Synthesis of 2-methyl-5-nitroquinazolin-4(3H)-one from 2-methyl-5-nitro-4H-benzo[d] oxazin-4-one: Amines reacted with 2-methyl-5-nitro-4H-benzo[d][1,3]oxazin-4-one to give respective quinazoline (Figure 5) [5].

(v) Synthesis of quinazoline-2,4 $(1 \mathrm{H}, 3 \mathrm{H})$-dione: Anthranilic acid and potassium cyanate reacted to get o-ureidobenzoic acid followed by cyclization by heating with acid or base to result in respective quinazoline-2,4 $(1 \mathrm{H}, 3 \mathrm{H})$-dione (Figure 6) [10].

(vi) Synthesis of 2-phenylquinazolin-4(3H)-one: 2-aminobenzamide reacted with styrene using Di-tertiary-butyl peroxide (DTBP) and p-Toluene sulfonic acid ( $\mathrm{p}-\mathrm{TsOH})$ to get 2-phenylquinazolin-4(3H)-one (Figure 7) [11].

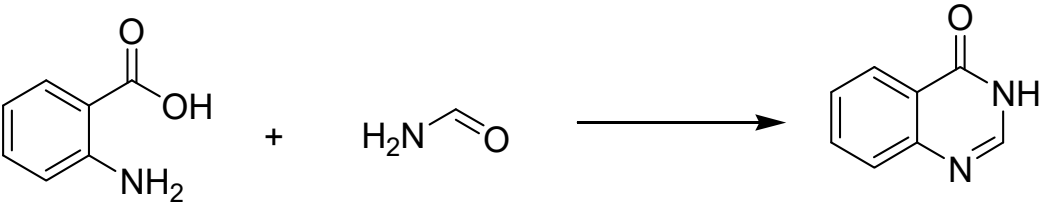

Figure 2. Synthesis of 3,4 dihydro-4-oxaquinazoline.

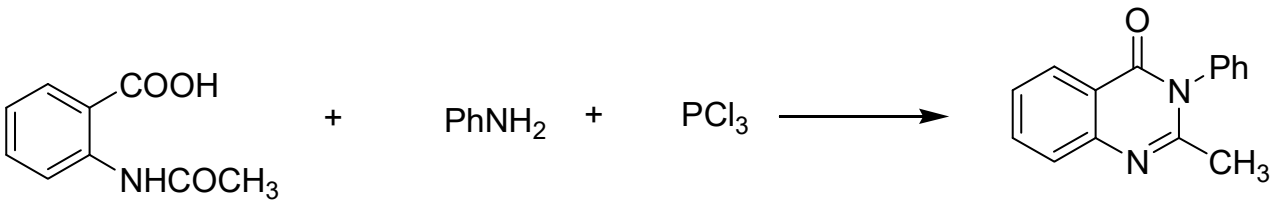

Figure 3. Synthesis of 2-methyl-3-phenylquinazolin-4(3H)-one. 
<smiles>CCOc1ccc(C(N)=O)c(C(C)C)c1</smiles>

Figure 4. Synthesis of quinazolin-4(3H)-one.<smiles>Cc1nc2cccc([N+](=O)[O-])c2c(=O)o1</smiles><smiles>[CH-]C</smiles><smiles>Cc1nc2cccc([N+](=O)[O-])c2c(=O)[nH]1</smiles>

Figure 5. Synthesis of 2-methyl-5-nitroquinazolin-4(3H)-one.<smiles>NC(=O)Nc1ccccc1C(=O)O</smiles>

Figure 6. Synthesis of quinazoline-2,4(1H,3H)-dione.<smiles>C=Cc1ccccc1</smiles>

Figure 7. Synthesis of 2-phenylquinazolin-4(3H)-one.

\section{Pharmacological Significance of Quinazoline Derivatives}

Quinazoline and quinazolinone based molecules are significant in pharmaceutical chemistry because of their broad range of medicinal and therapeutic activities, such as anti-tumor, antifungal, anti-inflammatory, antibacterial, antioxidant and other activities. Certain synthesized molecules having quinazoline moieties exhibited anticancer activity, such as epidermal growth factor receptor (EGFR) inhibitory activity with half maximal inhibitory concentration $\left(\mathrm{IC}_{50}\right)$ values equal to known drugs. Table 1.

There are several approved drugs in the market with quinazoline moiety, as shown in

Table 1. Quinazoline based commercial drugs.

S. no. Commercial Name Structure $\quad$ Ref.


Table 1. Cont.

\begin{tabular}{|c|c|c|c|c|}
\hline S. no. & Commercial Name & Structure & Usage & Ref. \\
\hline 2. & Prazocin & & For high blood pressure & [13] \\
\hline 3. & Erlotinib & & $\begin{array}{l}\text { For non-small cell lung } \\
\text { cancer, pancreatic cancer and } \\
\text { several other types of cancer }\end{array}$ & [14] \\
\hline 4. & Letermovir & & Antiviral drug & [15] \\
\hline 5. & Vandetanib & & $\begin{array}{l}\text { Antagonist of the vascular } \\
\text { endothelial growth factor } \\
\text { receptor }\end{array}$ & [16] \\
\hline 6. & Dacomitinib & & $\begin{array}{l}\text { Non small cell lung } \\
\text { carcinoma }\end{array}$ & [17] \\
\hline 7. & Afatinib & & $\begin{array}{l}\text { For treatment of cancers } \\
\text { resistant to gefinitib and } \\
\text { erlotinib }\end{array}$ & [18] \\
\hline
\end{tabular}


Table 1. Cont.

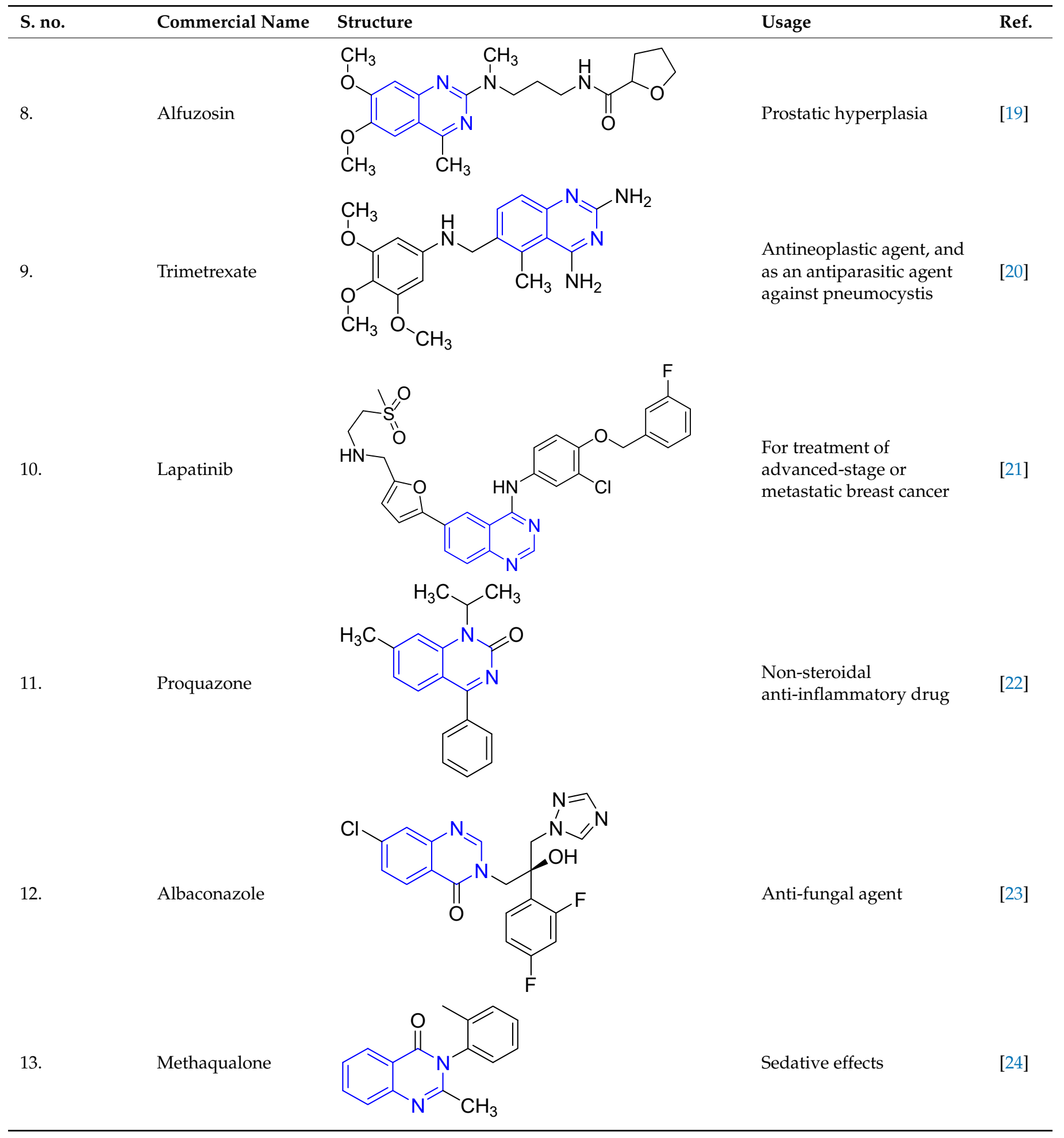


Table 1. Cont.

S. no. Commercial Name Structure $\quad$ Usage

\section{Quinazoline as Anti-Tumor Agents}

Quinazoline and its numerous derivatives can be extracted from plants. The substituted quinazoline has been widely used as an anti-tumor agent due to its structure-activity relationship. Many studies reported several synthesis derivatives of quinazoline and elucidated their promising characteristics as anticancer agents against various tumors. Recent developments in quinazoline derivatives are highlighted in this study.

A series of triazolo[4,3-c] quinazolines were prepared by Eves et al. [26]. Antitumor activity of synthesized compounds was tested against HepG2, MCF-7, PC-3, HCT-116 and HeLa cancer cell lines. Results showed strong EGFR inhibitory activity and the competence of the simulating cell cycle can arrest at the G2/M phase (Table 2, Compound 1). Molecular modelling was performed to study active site interaction and found a good relation with biological results. 6-Bromo-2-(pyridin-3-yl)-4-substituted quinazolines series were synthesised with the starting reagent 4-chloro derivative [27]. Human cancer cell lines MCF7 (breast) and A549 (lung) were used to evaluate the in vitro cytotoxicity. Synthesized compound $\mathrm{N}$-(benzo[d]thiazol-2-yl)-6-bromo-2-(pyridin-3-yl) quinazolin-4-amine (Table 2, Compound 2) was found to be extremely selective and potent against EGFR inhibition $\left(\mathrm{IC}_{50}=0.096 \mu \mathrm{M}\right)$ and as showing anticancer activity against the MCF-7 cell line $\left(\mathrm{IC}_{50}=2.49 \mu \mathrm{M}\right)$. Binding mode was found to be constant with the EGFR inhibitory activity in molecular docking studies of the shown compound. 6- and 7-substituted amino-4-anilinequinazoline derivatives were prepared by Das et al. [28] and tested for anticancer activity as irreversible dual EGFR/HER2 inhibitors. Synthesized compounds (Table 2, Compound 3) were found to be the most potent with reference to afatinib and osimertinib with the $\left(\mathrm{IC}_{50}=0.23 \mathrm{nM}\right)$ and $\left(\mathrm{IC}_{50}=1.28 \mathrm{nM}\right)$, which is better than AZD9291 $\left(\mathrm{IC}_{50}=0.44 \mathrm{nM}\right)$, afatinib $\left(\mathrm{IC}_{50}=1.39 \mathrm{nM}\right)$ and gefitinib $\left(\mathrm{IC}_{50}=0.42 \mathrm{nM}\right)$.

A series of quinazoline derivatives was prepared by the structural modification at the 6- and 7-position of quinazoline core. The most potent derivative (Table 2, Compound 4) obtained in this series was observed as a multi-kinase inhibitor and also shows effective cellular anti-proliferative activity against several cancer cell lines [29].

Quinazoline derivatives bearing benzene sulfonamides moieties were prepared and tested for antitumor activity by El-Azab et al. [30]. Synthesized compounds (Table 2, Compound 5) were found most potent against carbonic anhydrase (CA) inhibitory activity. Activity was compared with the reference drug acetazolamide, a typical sulphonamide inhibitor.

Rahmannejadi et al. [31] synthesized a very new series of bis-quinazolin-4(3H)-ones derivatives and evaluated them for their antitumor activity. Bromo derivatives of this compound were found to have the maximum potential of cytotoxic activity over dibromo or dimethyl compounds. Most competent derivatives are shown in Table 2, Compound 6.

Quinazoline derivatives having 3-substituted 2-thioxo-2,3-dihydro-1H-quinazolin4-one moiety were synthesized by Khodiar et al. [32]. Antitumor activity was evaluated 
against MCF-7 and HepG2 cell lines and found to be potent as a cell inhibitor with IC $_{50}$ values of 2.09 and $2.08 \mu \mathrm{M}$ against MCF-7 and HepG2, respectively (Table 2, Compound 7).

A series of 3-methyl-quinazolinone derivatives was designed and prepared by Le et al. [33]. Antitumor activity of synthesized compounds was tested in three human cancer cell lines including A549, PC-3 and SMMC-7721. Selected compounds as in Table 2, Compound 8, 2-f4-[(3-Fluoro-phenylimino)-methyl]-phenoxymethylg-3- methyl3 H-quinazolin-4-one, 2-f4-[(3,4-Difluoro-phenylimino)-methyl]-phenoxymethylg-3-methyl3Hquinazolin- 4-one and 2-f4-[(3,5-Difluoro-phenylimino)-methyl]-phenoxymethylg-3methyl-3H-quinazolin- 4-one, were found to be the most potent inhibitor of EGFR with an $\mathrm{IC}_{50}$ value of $10 \mathrm{nM}$.

Quinazoline derivatives containing piperazine moiety were prepared via substitution reactions with 6,7-disubstituted 4-chloroquinazoline and benzyl piperazine. Antitumor activity of the synthesized compound was evaluated against A549, HepG2, K562 and PC-3 cellines. Out of all the synthesised compounds, N-(3-chlorophenyl)-2-(4-(7-methoxy-6(3-morpholino-propoxy) quinazoline-4-yl)piperazine-1-yl)acetamidename (Table 2, Compound 9) was found to have outstanding activity [34].

A series of 2-[(3-(4-sulfamoylphenethyl)-4(3H)-quinazolinon-2-yl)thio]anilide derivatives was prepared by Alkahtani et al. [35]. The cytotoxic activity of the derivatives was assessed against breast adenocarcinoma (MCF-7), colorectal adenocarcinoma (HT-29) and acute myeloid leukaemia (HL-60 and K562) cells along with human fibroblast cell line, MRC-5. Selected compounds exhibited (Table 2, Compound 10) excellent activity with the $\mathrm{IC}_{50}$ values of $0.34,0.28$ and $0.39 \mathrm{mM}$, respectively. The activity of these compounds was compared to sorafenib having an $\mathrm{IC}_{50}$ value of $0.11 \mu \mathrm{M}$.

One more series of quinazoline derivatives has been synthesised by alkylation, and hydrazinolysis of the inherent thioxo group gives corresponding thioethers [36]. Compounds shown (Table 2, Compound 11) had great activity against the used cell-lines with $\mathrm{IC}_{50}$ values ranging from 1.85 to $2.81 \mathrm{lM}$ against HeLa and MDA-MB231 cells, respectively.

$\mathrm{Vu}$ et al. [37] synthesized quinazoline derivatives and evaluated their anticancer activity against SKLU-1 (Lung cancer), MCF-7 (breast cancer) and HepG-2 (liver cancer) cell lines inhibition. The synthesized compound 3-benzyl-2-methylquinazolin-4(3H)-one, as shown in Table 2, Compound 12, shows maximum cytotoxicity inhibition against cancer cell lines with $\mathrm{IC}_{50}$ values of $9.48,20.39$ and $18.04 \mu \mathrm{g} / \mathrm{mL}$

4-Arylamino-6-(5-substituted furan-2-yl)quinazoline derivatives were prepared by Zhang et al. [38]. Biological activities of synthesized compounds were assessed against SW480, A549, A431 and NCI-H1975 cells. The selected compounds shown in Table 2, Compound 13, had the maximum inhibitor activity toward wild type EGFR with $\mathrm{IC}_{50}=5.06 \mathrm{nM}$. Activity of these compounds was compared to commercially available Lapatinib and found to be significant.

Srinivas et al. [39] prepared a series of novel derivatives of quinazoline and tested their anticancer activity. Synthesized compounds 5-((3,4-dihydro-2-phenylquinazolin-4yloxy)methyl)- $N$-phenyl-1,3,4-thiadiazol-2-amine and 5-((3,4-dihydro-2-phenylquinazolin4-yloxy)methyl)- $N$-(2-nitrophenyl)-1,3,4-thiadiazol-2-amine as in Table 2, Compound 14, are the most potent glycogen synthase kinase (GSK-3) inhibitors and showed high hypoglycemic activity.

Quinazoline analogs, such as 1-(4-(4-((thiazol-2-yl)methoxy)-3-chlorophenylamino) quinazolin-6-yl)-3-(1-hydroxypropan-2-yl)thioure (a) and their derivatives as shown in Table 2, Compound 15, were designed and synthesized by Wallace et al. [40]. These synthesized analogs exhibited activity as receptor tyrosine kinase inhibitors.

R.A. Vishwakarma [41] synthesized 6-aryl-4-phenylamino-quinazoline analogs. Synthesized compounds (Table 2, Compound 16) 2-(4-(6-phenylquinazolin-4-ylamino)phenyl) acetonitrile (a), 2-(4-(6-(2,4-difluorophenyl)quinazolin-4-ylamino)phenyl)acetonitrile (b), 2(4-(6-(3-nitrophenyl)quinazolin-4-ylamino)phenyl)acetonitrile (c) and 2-(4-(6-o-tolylquinazolin4-ylamino)phenyl)acetonitrile (d) were found as phosphoinositide-3-kinase inhibitors against various cancers such as pancreatic, prostate, breast and melanoma. 
Table 2. Quinazoline based anti-tumor agents.

Compound no. Structure

(a)<smiles>N#CC1=CN(c2nnc3c4ccccc4nc(Sc4ccc(Br)cc4)n23)C(=O)C1</smiles>

(b)<smiles>Nc1nc(Nc2nnc3c4ccccc4nc(Sc4ccc(Br)cc4)n23)cs1</smiles>

(c)

2<smiles>Brc1ccc2nc(-c3cccnc3)nc(Nc3nc4ccccc4s3)c2c1</smiles><smiles>CCOCCOc1cc2ncnc(Nc3ccc(F)c(Cl)c3)c2cc1NC(=O)/C=C/CN(C)C</smiles>

3

(a)

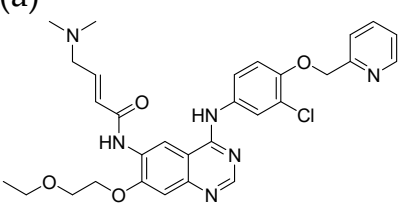

(b)
$\mathrm{IC}_{50}(\mathrm{uM})$

(a)

(i) $15.02 \pm 1.4$

(ii) $9.73 \pm 1.1$

(iii) $21.65 \pm 1.8$

(iv) $14.76 \pm 1.4$

(v) $18.93 \pm 1.6$

(i) HepG2,

(b)

(ii) $\mathrm{MCF}-7$

(iii) $\mathrm{PC}-3$

(iv) $\mathrm{HCT}-116$

(i) $15.30 \pm 1.4$

(ii) $8.58 \pm 1.3$

(iii) $10.58 \pm 1.5$

(iv) $13.47 \pm 1.7$

(v) $9.47 \pm 0.9$

(c)

(i) $10.30 \pm 1.7$

(ii) $8.90 \pm 1.9$

(iii) $10.54 \pm 1.2$

(iv) $11.47 \pm 1.6$

(v) $13.41 \pm 0.9$
(i) EGFR
(ii) $\mathrm{A} 549$
(iii) MCF7
(iv) WI38
(v) PC9
(vi) $\mathrm{HCC} 827$

$\mathrm{IC}_{50}(\mathrm{uM})$

(i) $0.096 \pm 0.00278 \mu \mathrm{M}$

(ii) $178.34 \pm 8.9$

(iii) $2.49 \pm 0.12$

(iv) $82.8 \pm 4.14$

(v) $1.05 \pm 0.02$

(vi) $3.43 \pm 0.066$
(a)
(i) 0.6
(ii) $107.0 / 12.2$
(iii) $0.2 / 0.3$
(iv) $20.0 / 1.52$
(b)
(i) 1.01
(ii) 60.6
(iii) 1.2
(iv) 288.3

(nM)

(i) EGFR

(ii) $\mathrm{NCIH} 1975$

(iii) $\mathrm{HCC} 827$ 
Table 2. Cont.

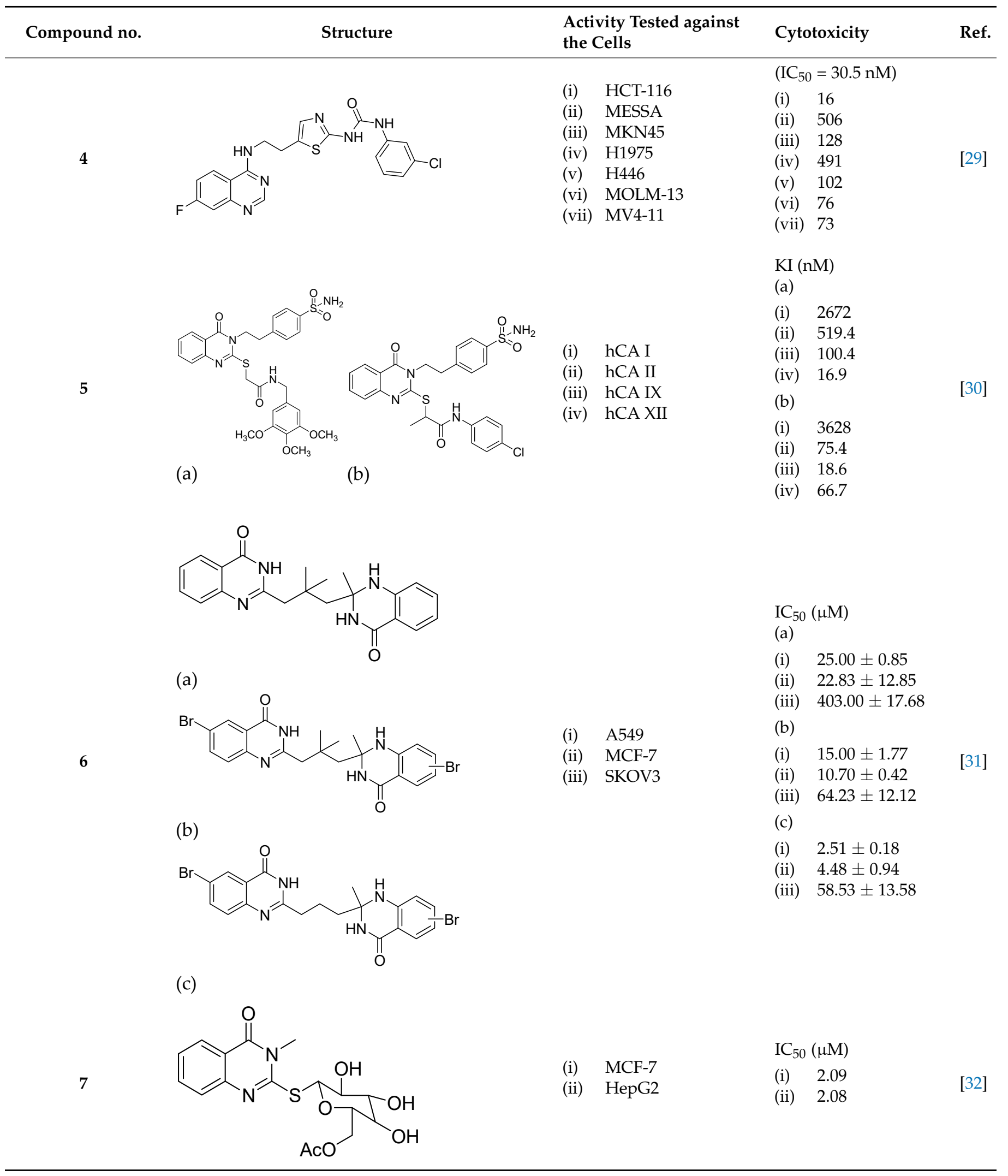


Table 2. Cont.

Compound no. Structure

(a)

8<smiles>Cn1c(COc2ccc(/C=N\c3ccc(F)c(F)c3)cc2)nc2ccccc2c1=O</smiles>

(b)<smiles>Cn1c(COc2ccc(/C=N\c3cc(F)cc(F)c3)cc2)nc2ccccc2c1=O</smiles>

(c)

9<smiles>COc1cc2ncnc(N3CCN(CC(=O)Nc4cccc(Cl)c4)CC3)c2cc1OCCCN1CCOCC1</smiles><smiles>NS(=O)(=O)c1ccc(CCn2c(S)nc3ccccc3c2=O)cc1</smiles>

(a)

10<smiles>NS(=O)(=O)c1ccc(CCn2c(SCC(=O)Nc3ccc(F)cc3)nc3ccccc3c2=O)cc1</smiles>

(b)<smiles>NS(=O)(=O)c1ccc(CCn2c(SCC(=O)Nc3ccc(Cl)cc3)nc3ccccc3c2=O)cc1</smiles>

(i) EGFRwt-TK

(ii) A549,

(iii) PC-3, and

(iv) SMMC-7721 (a)

(i) $0.047 \pm 0.004$

(ii) $19.73 \pm 2.34$

(iii) $30.06 \pm 1.86$

(iv) $35.92 \pm 5.85$

(b)

(i) $0.010 \pm 0.001$

(ii) $12.30 \pm 4.12$

(iii) $17.08 \pm 3.61$

(iv) $15.68 \pm 1.64$

(c)

(i) $0.54 \pm 0.031$

(ii) $7.22 \pm 3.51$

(iii) $13.29 \pm 1.12$

(iv) $6.04 \pm 0.55$
(i) A549,
(ii) $\mathrm{PC}-3$
(iii) HepG2
(iv) $\mathrm{K} 562$

$\mathrm{IC}_{50}(\mu \mathrm{M})$
(i) $8.24 \pm 1.40$
(ii) $7.66 \pm 1.27$
(iii) $38.62 \pm 2.41$
(iv) $21.96 \pm 3.51$

$\mathrm{IC}_{50}(\mathrm{mM})$

(a)

(i) $0.65 \pm 0.15$

(ii) $4.60 \pm 1.08$

(iii) $1.71 \pm 0.01$

(iv) $3.67 \pm 0.43$

(v) $13.46 \pm 2.19$
(i) $\mathrm{MCF}-7$
(ii) HT-29
(iii) HL-60
(iv) K562
(v) MRC-5

(b)

(i) $3.86 \pm 0.78$

(ii) $3.56 \pm 1.09$

(iii) $1.50 \pm 0.14$

(iv) $0.42 \pm 0.10$

(v) $7.07 \pm 0.41$

(c)

(i) $1.04 \pm 0.07$

(ii) $1.43 \pm 0.45$

(iii) $0.41 \pm 0.02$

(iv) $2.03 \pm 0.40$

(v) $\quad 3.77 \pm 1.21$ 
Table 2. Cont.

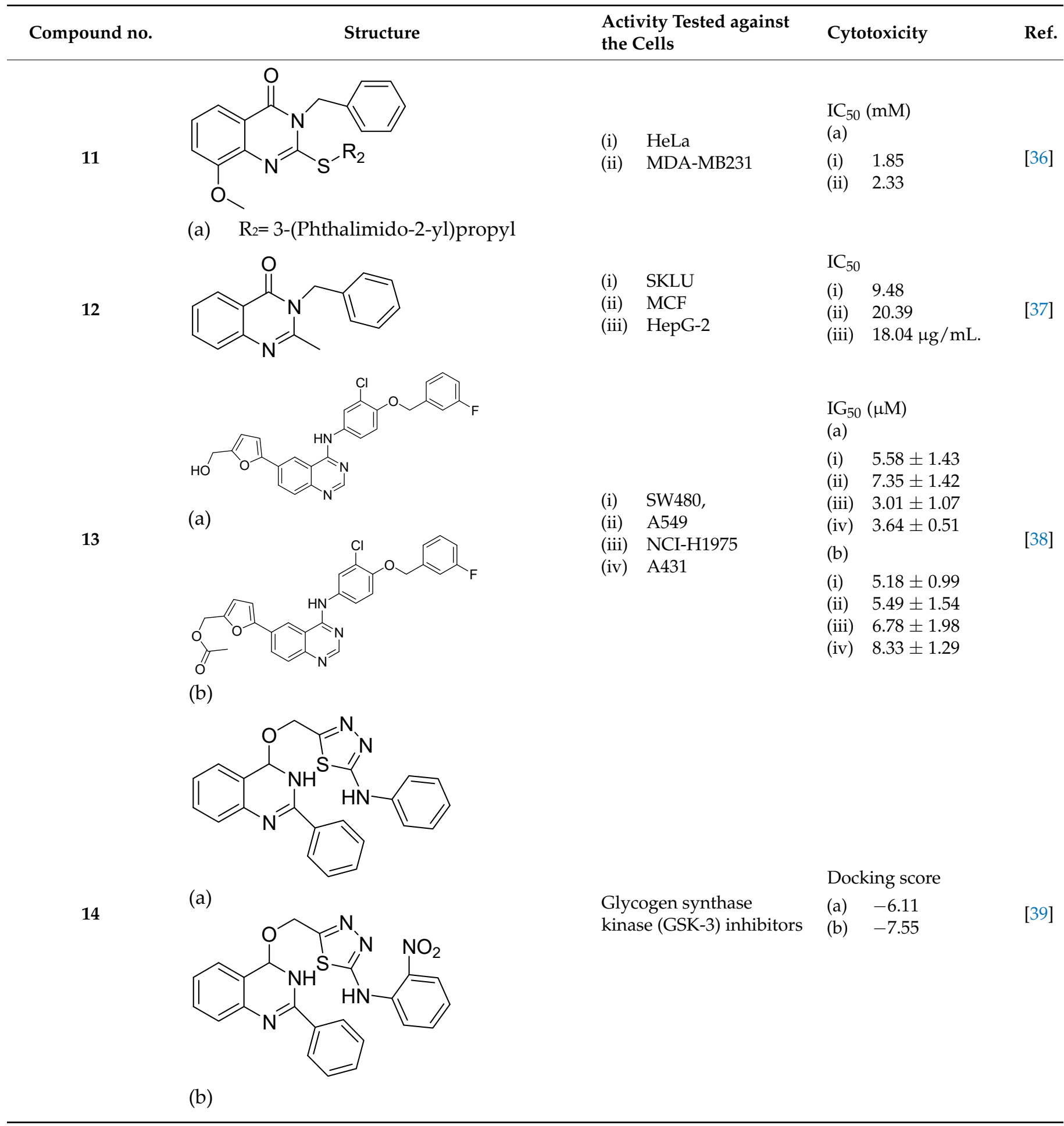


Table 2. Cont

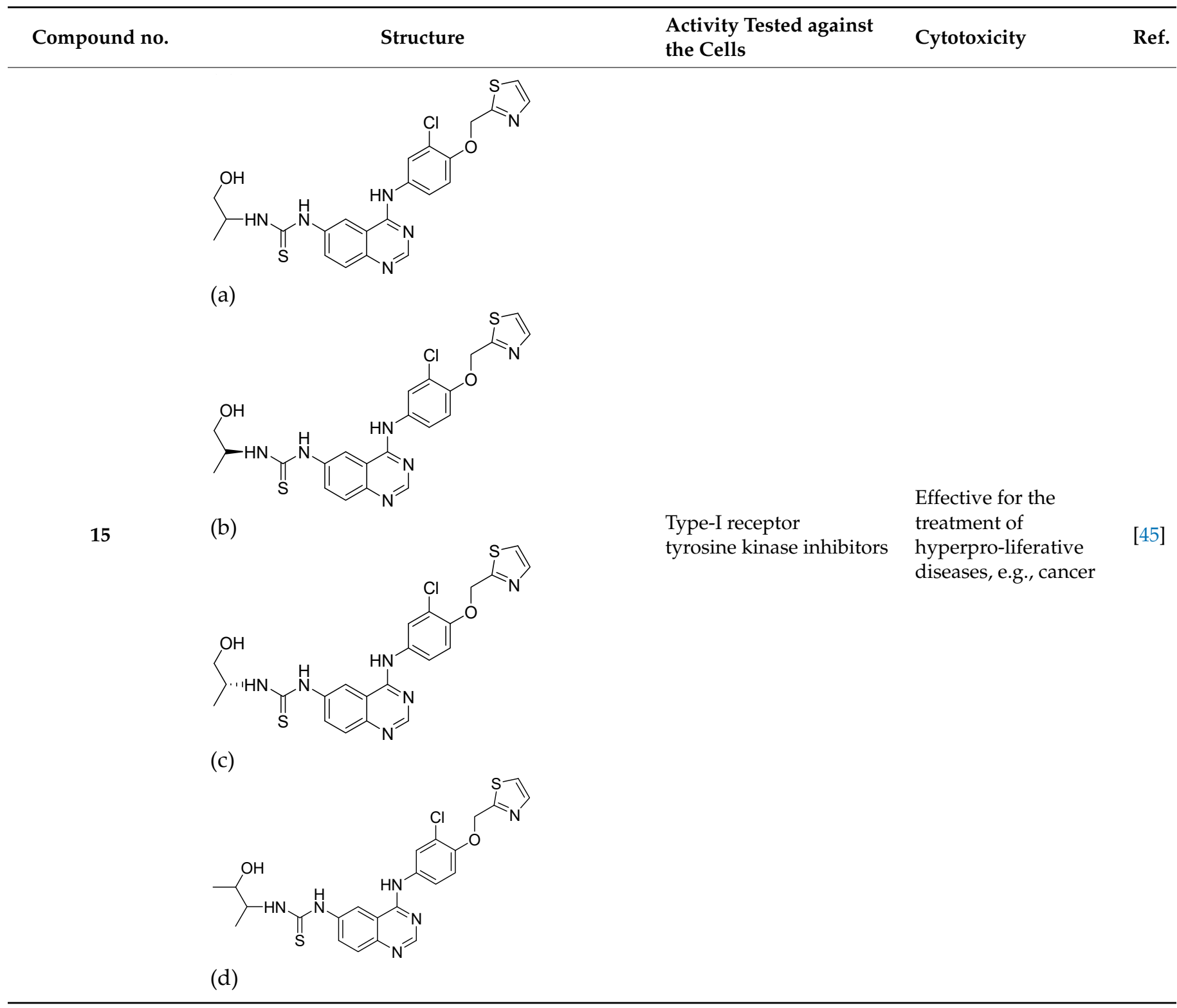


Table 2. Cont.

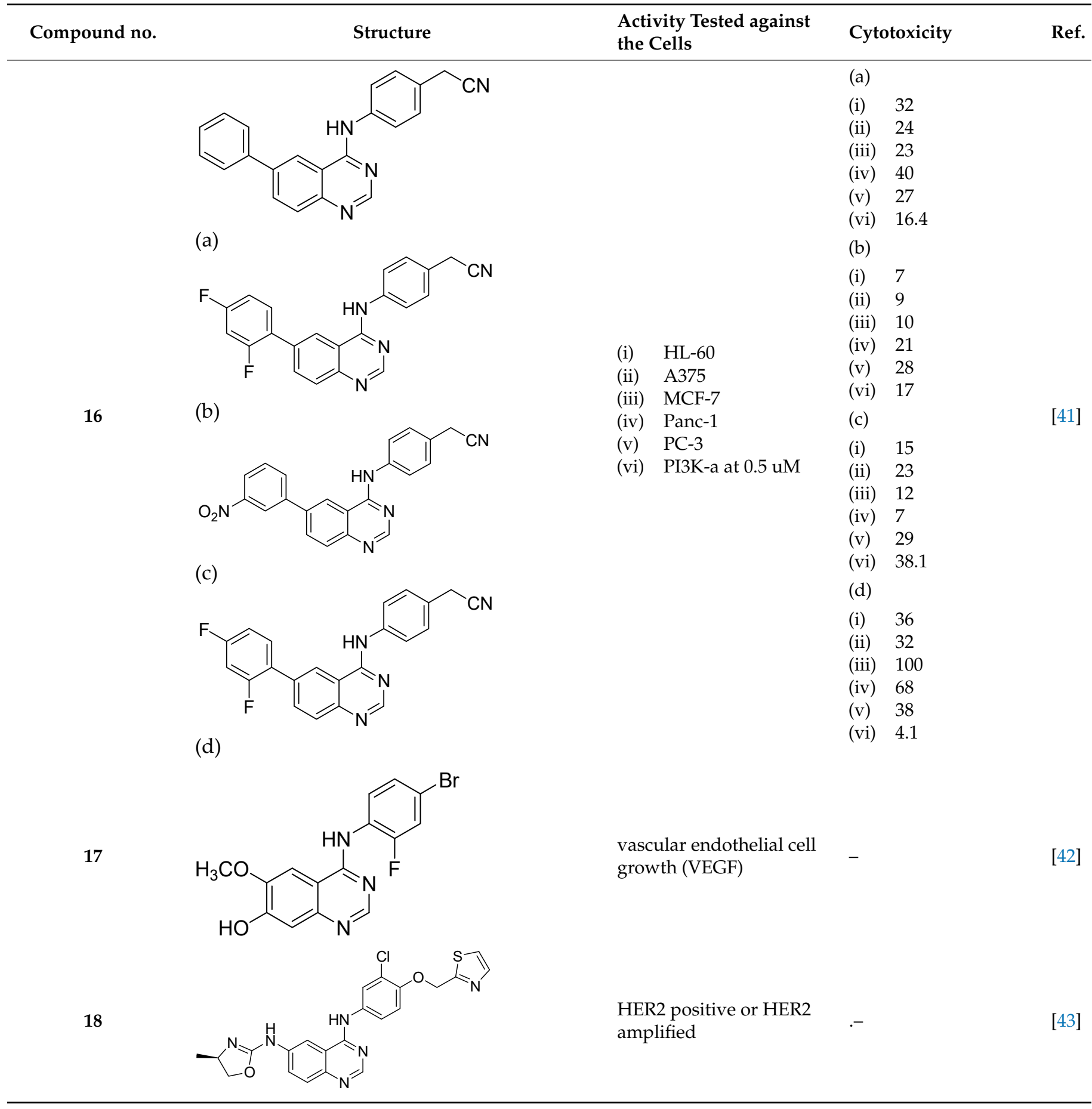


Table 2. Cont.

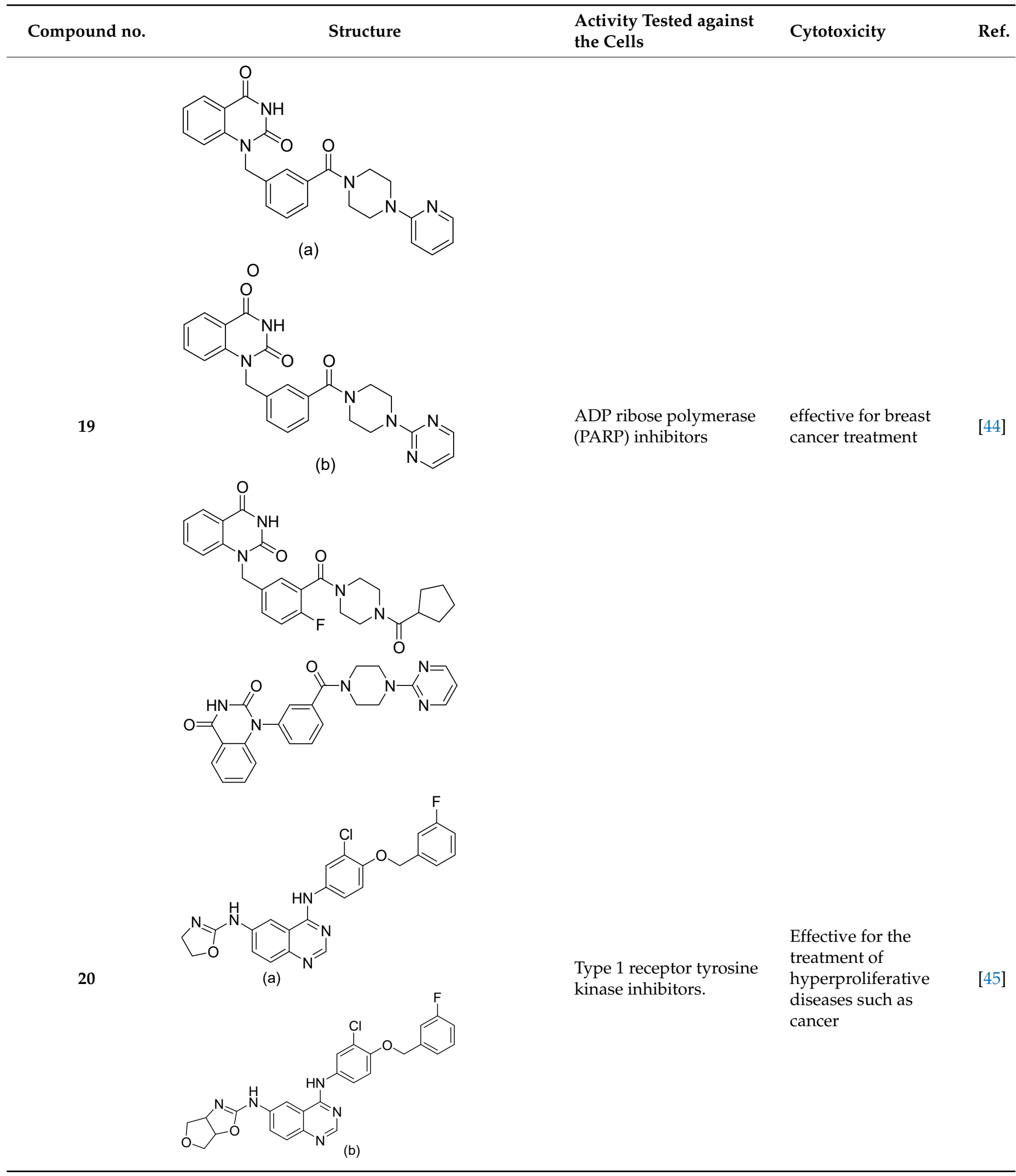


Table 2. Cont

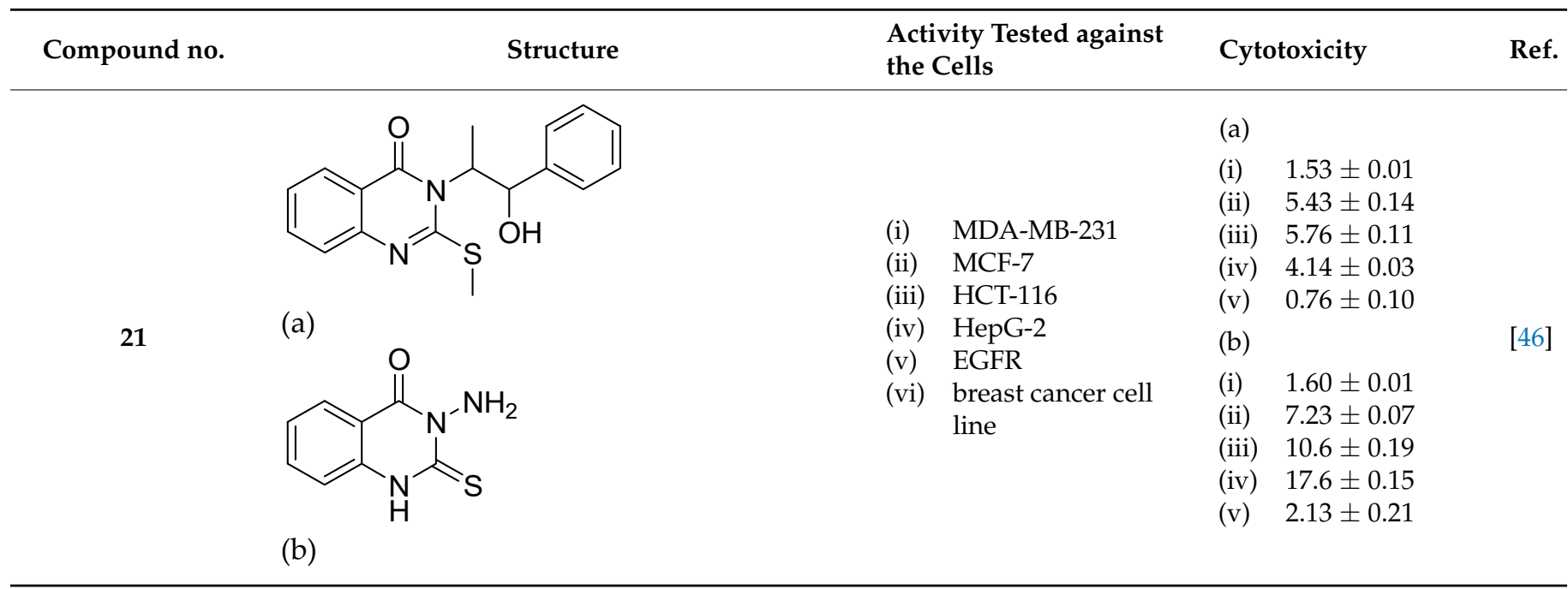

Synthesis of 4-(4-bromo-2-fluoroanilino)-6-methoxy-7-(1-methylpiperidin-4-ylmethoxy) quinazoline analogs was performed by Golden et al. [42]. Synthesized compound 4-(4bromo-2-fluorophenylamino)-6-methoxyquinazolin-7-ol as in Table 2, Compound 17, is a potent inhibitor of vascular endothelial cell growth (VEGF) RTK, and also exhibits activity against epidermal growth factor.

Lindmark et al. [43] published a patent for synthesized quinazoline analog and used as anticancer agents. Synthesized compound N4-(4-((thiazol-2-yl)methoxy)-3-chlorophenyl)N6-((R)-4,5-dihydro-4-methyloxazol-2-yl)quinazoline-4,6-diamine as in Table 2, Compound 18, shows remarkable anti-cancer activity.

Ci et at. [44] have also synthesized and patented novel 1-(aryl methyl) quinazoline-2, 4 $(1 \mathrm{H}, 3 \mathrm{H})$-ones analogs. Synthesized compounds as shown in Table 2, Compound 19, were used as poly ADP ribose polymerase (PARP) inhibitors, which is effective for the breast cancer treatment.

Wallace et al. [45] have synthesized quinazoline analogs. Synthesized compounds N4(4-(3-fluorobenzyloxy)-3-chlorophenyl)-N6-(4,5-dihydrooxazol-2-yl)quinazoline-4,6-diamine, and N4-(4-(3-fluorobenzyloxy)-3-chlorophenyl)-N6-(3a,4,6,6a-tetrahydrofuro[3,4-d]oxazol2-yl)quinazoline-4,6-diamine as in Table 2, Compound 20, were used as type 1 receptor tyrosine kinase inhibitors.

A new set of quinazolinone analogs were synthesized by using L-norephedrinewas as a basic unit by Ghorab et al. [46]. The cytotoxicity of synthesized compounds was evaluated against the MDA-MB-231, MCF-7, HepG-2, HCT-116 cancer cell lines along with the EGFR activity. Synthesized compounds 3-(1-hydroxy-1-phenylpropan-2-yl)-2(methylthio)quinazolin-4(3H)-one and its analog, as shown in Table 2, Compound 21, were reported as potent molecules against breast cancer cell line.

\section{Quinazoline as Anti-Viral}

Antiviral activity of a molecule is entirely related to the compounds that either kill the virus or reduce its growth rate without displaying any toxicity to the host and nearby tissues. The various derivatives of quinazoline have been explored to show significant antiviral activities as discussed.

A series of 2,4 disubstituted quinazoline derivatives with many amide groups were synthesized and tested for antiviral activity as a drug for anti-influenza [47]. The SAR studies exhibited that synthesized compounds 2-(2-(dimethylamino) quinazolin-4-yloxy)-Nphenylacetamide and $\mathrm{N}$-(2-(2-(3,4-dihydroisoquinolin-2(1H)-yl)quinazolin-4-yloxy)ethyl) benzamide as shown in Table 3, Compound 1, are the most active compounds having highest anti-influenza virus activity with $\mathrm{IC}_{50}$ of less than $10 \mu \mathrm{M}$. 
To eliminate the side effects and disadvantages of HCV, Rothan et al. [48] designed a new series of quinazoline derivatives and evaluated their biological activity as antiviral agents. Synthesized compounds as in Table 3, Compound 2, show remarkable activity against HCV NS3-4Apro with a considerable reduction in Renilla luciferase (Rluc) activities at $40 \mu \mathrm{M}$.

Based on the pharmacophore hybrid approach, quinazoline derivatives were synthesized having 1,2,4-triazole thioether moiety and tested for their antibacterial and antifungal activities. Synthesized compounds have shown potent inhibition activity against the Gramnegative bacteria, e.g., bacterium Xanthomonas axonopodis pv. citri (Xac), Xanthomonas oryzae pv. oryzae (Xoo) and Ralstonia solanacearum (Rs). Synthesized compounds ethyl 2-(5-amino1-(quinazolin-4-yl)-1H-1,2,4-triazol-3-ylthio) acetate and their derivatives as in Table 3, Compound 3, have shown prominent inhibition activity against phytopathogenic bacteria. These compounds exhibited $\mathrm{EC}_{50}$ values of $46.9,47.8$ and $43.2 \mu \mathrm{g} / \mathrm{mL}$, respectively, against the bacterium Xanthomonas axonopodis pv. Citri which were more effective than marketed drug agrobactericide Bismerthiazol $(56.9 \mu \mathrm{g} / \mathrm{mL})$ [49].

Table 3. Antiviral activity of quinazoline derivatives.

Compound no.


Table 3. Cont.

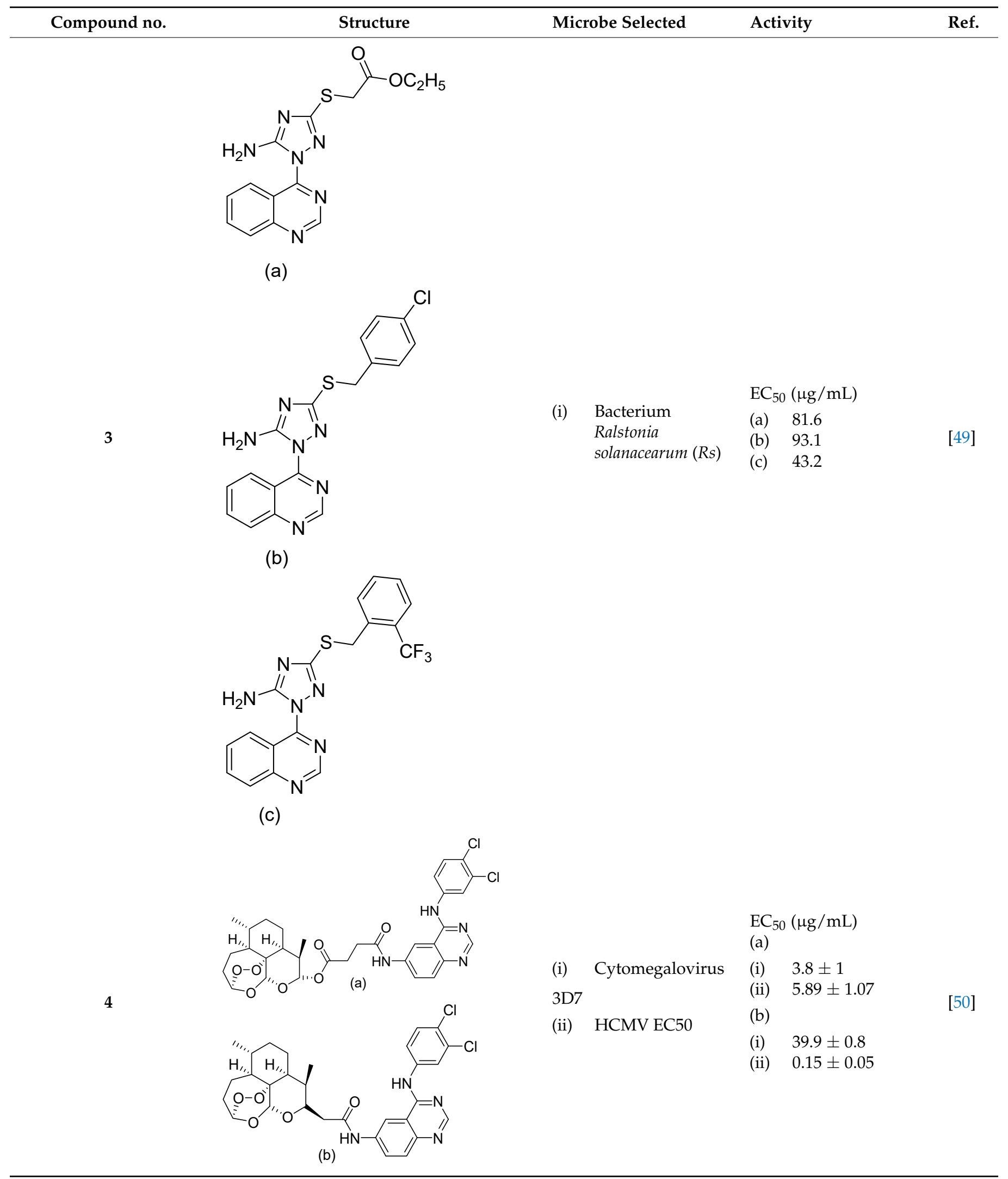


Table 3. Cont.

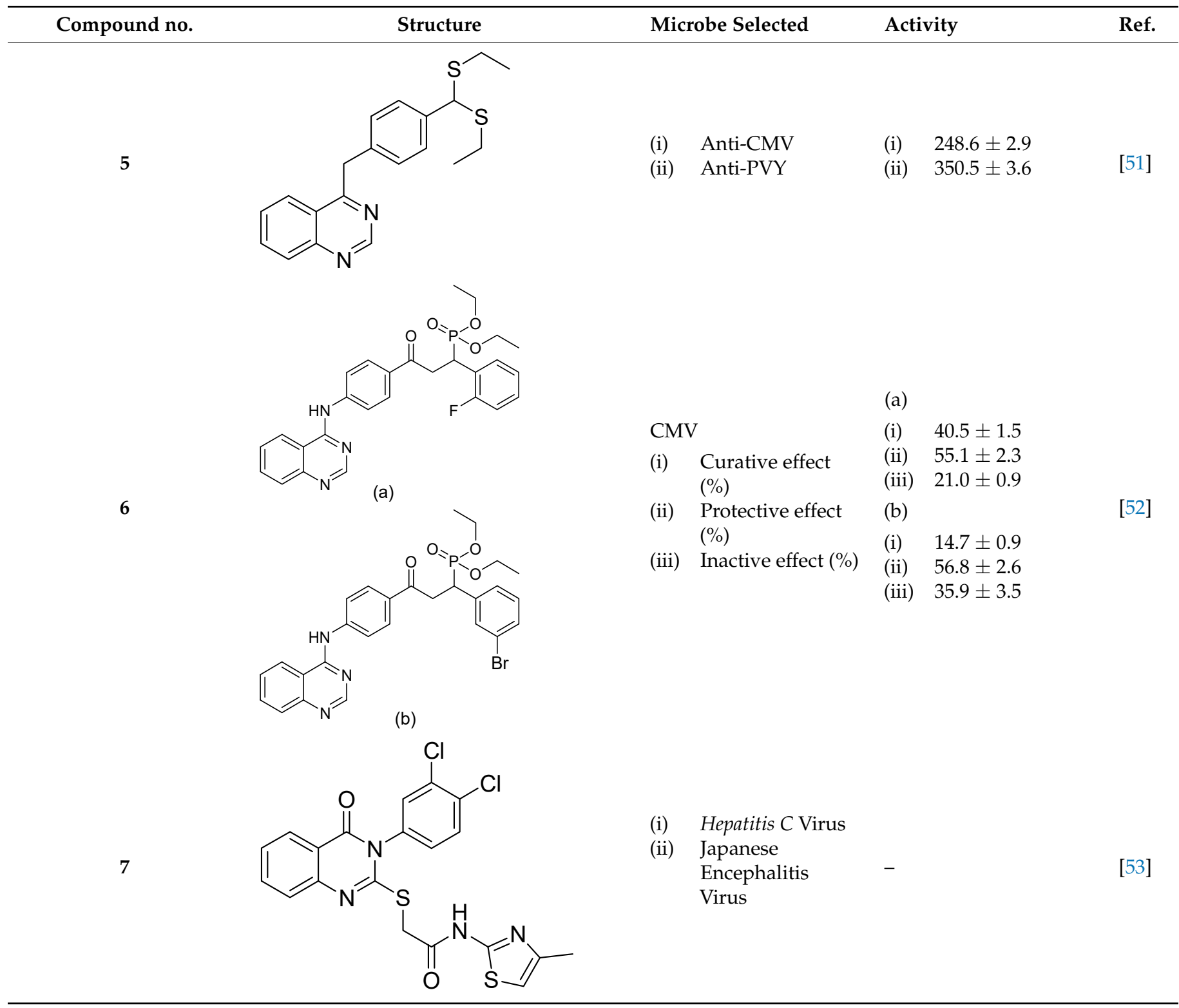

Quinazoline artemisinin hybrids were synthesized and evaluated for their in vitro biological activity. Novel quinazoline artemisinin hybrids were synthesized and evaluated for their antiviral activity [50]. Synthesized hybrids as in Table 3, Compounds $\mathbf{4 ( a )}$ and (b), were found to have most potent activity against cytomegalovirus having $\mathrm{EC}_{50}=0.15-0.21$ $\mu \mathrm{M}$. These compounds were compared with ganciclovir having $\mathrm{EC}_{50}=2.6 \mu \mathrm{M}$ and found to be superior by a factor of $12-17$.

Dithioacetal moiety containing quinazoline derivatives were synthesized as an antiviral agent with reference to ningnanmycin. The prepared compound 4-(4-(bis(ethylthio)methyl) benzyl) quinazoline as in Table 3, Compound 5, found to have maximum therapeutic effectiveness against CMV (cucumber mosaic virus) with EC50 $=248.6 \mu \mathrm{g} / \mathrm{mL}$ and potato virus $\mathrm{Y}\left(\mathrm{EC}_{50}=350.5 \mu \mathrm{g} / \mathrm{mL}\right)$, which is better than commercially available ningnanmycin (357.7 $\mu \mathrm{g} / \mathrm{mL}$ and $493.7 \mu \mathrm{g} / \mathrm{mL}$, respectively) [51].

1,4-hydrophosphinylation of $\alpha, \beta$-unsaturated carbonyl compounds have been applied for the synthesis of chalone-like compounds. Antiviral activity was tested against the cucumber mosaic virus. Selected compounds in Table 3, Compound 6, reveal protective 
activities at $55.1 \%$ and $56.8 \%$, respectively, which is comparable to the marketed drugs ningnanmyin (49.3\%) and dufulin (53.1\%) [52].

Quinazoline analogs have been used for treating or preventing certain viral infection, specifically, Hepatitis $C$ virus and Japanese Encephalitis virus [53]. Synthesized compounds 2-(3-(3,4-dichlorophenyl)-3,4-dihydro-4-oxoquinazolin-2-ylthio)- $N$-(4methylthiazol-2-yl)acetamide, as in Table 3, Compound 7, were found to be potent antivirals and these quinazoline analogs were used.

\section{Quinazoline as Anti-Bacterial}

Various researches have confirmed the antibacterial activity of quinazolinone derivatives higher than of standard drugs. This is due to the structural features of these analogs which is the main reason of the interest for research in this area.

Misra et al. [54] have synthesized a new series of quinazoline embellished analogues of 1,5-benzodiazepine and evaluated their antibacterial activity. Synthesized compounds ( $Z$ )3-(2-phenylquinazolin-4-yl)-1H-benzo[b][1,4]diazepin-2(5H)-one and (E)-4-(methylthio)-3(2-phenylquinazolin-4-yl)-1H-benzo[b][1,4]diazepin-2(5H)-one as shown in Table 4, Compound 1, were observed to be highly potent, which showed to be highly effective against Staphylococcus aureus and Escherichia coli.

Table 4. Antibacterial activity of quinazoline derivatives.

Compound no.


Table 4. Cont.

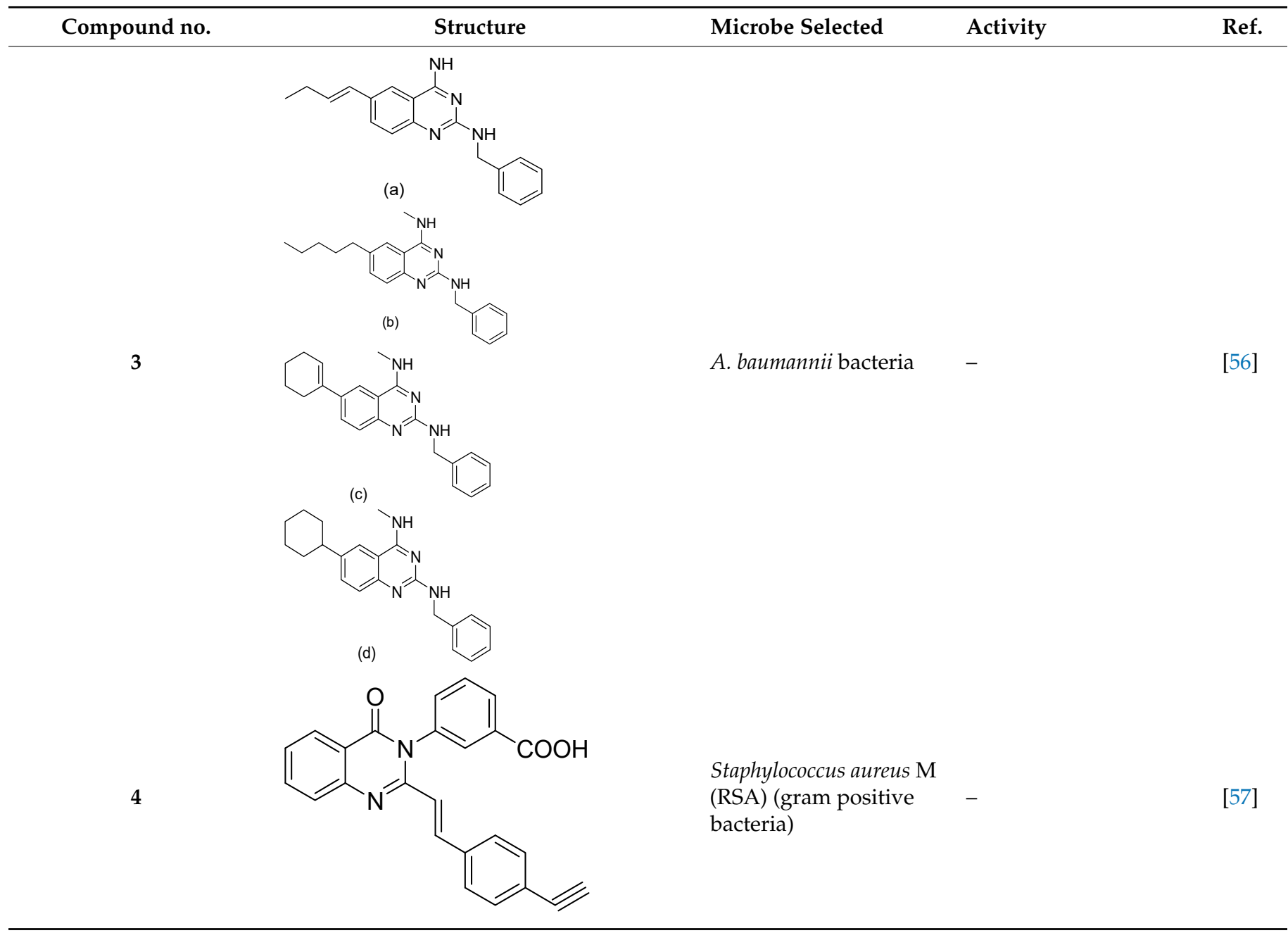

Kumar et al. [55] synthesized novel series of 4-amino- $N$-(phenyl)benzenesulfonamides derivative and evaluated their antimicrobial activity. Chloro-derivative of synthesized compounds as in Table 4, Compound 2, were found to be most potent candidate against the gram-negative bacteria strain.

Peter et al. [56] have synthesized disubstituted quinazoline-2,4 diamines analogs. Synthesized compounds N2-benzyl-N4-methyl-6-((E)-pent-1-enyl)quinazoline-2,4-diamine and its analogs as shown in Table 4, Compound 3, are effective to kill and to prevent Acinetobacter baumannii bacteria.

A new class of compounds was synthesized by Chang et. al. [57]. The synthesized compound 3-(2-(4-ethynylstyryl)-4-oxoquinazolin-3(4H)-yl) benzoic acid as in Table 4, Compound 4 , is a highly effective antibiotic against gram positive bacteria, viz., S. aureus M (RSA).

\section{Quinazoline as Anti-Tubercular Activity}

TB is one of the most prevalent and contagious diseases. Quinazoline molecules have been explored as a potent scaffold for anti-tubercular activity. The following studies explored the strong approach of quinazoline derivatives as biologically active antitubercular agents.

Thirty two compounds were prepared using benzimidazo quinazoline as scaffold [58] and tested for biological activity as anti-tubercular activity. Prepared compounds 6Propylbenzo[4,5]imidazo[1,2-c]quinazoline (a) and 2-Methyl-6-propylbenzo[4,5]imidazo[1,2clquinazoline (b) as shown in Table 5, Compound 1, were found to be the most potent 
compounds against $M$. tuberculosis with MIC values in the range of 12.5 and $0.78 \mu \mathrm{g} / \mathrm{mL}$, respectively.

Table 5. Antitubercular activity of quinazoline derivatives.

Compound no.

6-(trifluoromethyl)-N-(4-oxothiazolidin-3-yl)quinazoline-2-carboxamide derivatives (Table 5, Compound 2) have been designed as an antitubercular agent for the inhibition of DprE1 [59]. Compounds with nitro and hydroxyl groups have maximum antitubercular activity against Mycobacterium tuberculosis H37RV.

Lupien et al. have synthesized new derivatives of 2-Ethylthio-4-methylaminoquinazoline and evaluated for their biological activity against Mycobacterium tuberculosis (M. tb) [60]. It was concluded that quinazoline based derivatives are a potent moiety for the tuberculosis drug targeting (Table 5, Compound 3).

\section{Quinazoline as Anti-Oxidant Activity}

Excessive formation of free radicals due to oxidative stress need to be supressed in the human body. Developments of antioxidative agents are the one major necessity in the area of drug designing, as the antioxidant can defend the body due to the damage by free radicals. Antioxidative properties of quinazolines derivative is a recent and emerging concern.

Synthesis of novel 2-thioxobenzo quinazoline with their analogs was performed by Salahi et al. [61] and tested as anti-oxidant. Synthesized benzoquinazolines as shown in Table 6, Compound 1, were found to have high DPPH and free radical scavenging activities along with the reduction competence. Butylated hydroxyl toluene (BHT) was taken as the reference compound. 
Table 6. Antioxidant activity of quinazoline derivatives.

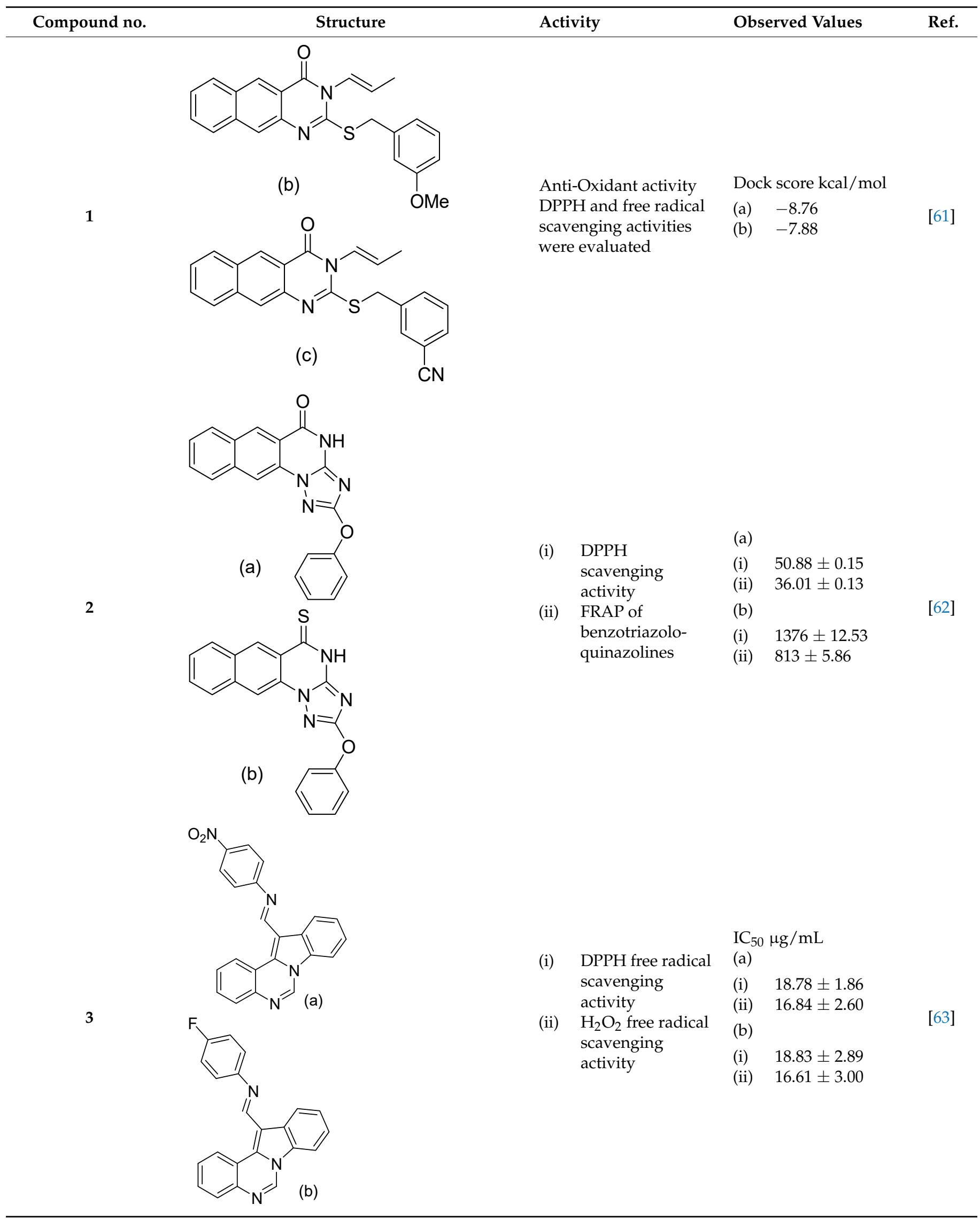


Table 6. Cont.

\begin{tabular}{lllll}
\hline Compound no. & Activity & Observed Values \\
\hline
\end{tabular}

Novel analogs of 2-phenoxy benzo triazoloquinazoline were prepared by Almehizia et al. [62]. These compounds were tested for their biological activity as anti-oxidant by using three different assays. The results showed that benzotriazoloquinazoline derivative has good antioxidant activities with the capability of scavenging the free radicals. The synthesized compounds as shown in Table 6, Compound 2, were found to exhibit the highest antioxidant activity. BHT was taken as the reference agent.

Dixit et al. [63] synthesized a series of quinazoline analogs and tested them for their biological activity as antioxidant activity. Analogs synthesized (14E)-N-((H-indolo[1,2c]quinazolin-12-yl)methylene)-4-nitrobenzenamine (a) and its flouro (b) derivatives as shown in Table 6, Compound 3, were found to have maximum activity as antioxidants with an $\mathrm{IC}_{50}$ value of $18.78 \pm 1.86 \mu \mathrm{g} / \mathrm{mL}, 16.84 \pm 2.60 \mu \mathrm{g} / \mathrm{mL}$ and $18.64 \pm 2.40 \mu \mathrm{g} / \mathrm{mL}$, respectively.

A new series of 2, 3 substituted quinazolinones analogs were synthesized and tested for their biological activity [64]. Antioxidant activity was tested by DPPH-radical-scavenging, reducing power and total antioxidant status (TAS) assay. Synthesized compounds as shown in Table 6, Compound 4, possess antioxidant activity.

\section{Quinazoline as Anti-Convulsant}

Novel 2,3-disubstituted-4-(3H) quinazolinone derivatives were prepared and evaluated for their anti-convulsant activity [65]. The synthesized drug was used against electroshock-induced seizures and PTZ-induced clonic seizures. Compounds as in Table 7, Compound 1, were screened for anticonvulsant activity and found to be the most potent anti-convulsant and carbamazepine.

Table 7. Miscellaneous activities of quinazoline derivatives.

\begin{tabular}{|c|c|c|c|c|}
\hline Compound no. & Structure & Activity & Results & Ref. \\
\hline 1 & & $\begin{array}{l}\text { Evaluated as } \\
\text { anti-convulsant activity }\end{array}$ & $\begin{array}{l}\text { Synthesized } \\
\text { compounds were } \\
\text { performed against } \\
\text { maximal } \\
\text { electroshock-induced } \\
\text { seizures and } \\
\text { PTZ-induced clonic } \\
\text { seizures }\end{array}$ & [65] \\
\hline 2 & $\mathrm{DH}$ & $\begin{array}{l}\text { Evaluated as } \\
\text { anti-inflammatory } \\
\text { agent }\end{array}$ & $\begin{array}{l}\text { Synthesized } \\
\text { compounds showed } \\
\text { high anti-inflammatory } \\
\text { activity. Fluorine atom } \\
\text { has crucial role in the } \\
\text { anti-inflammatory } \\
\text { activity of the } \\
\text { synthesized } \\
\text { compounds }\end{array}$ & [66] \\
\hline
\end{tabular}


Table 7. Cont.

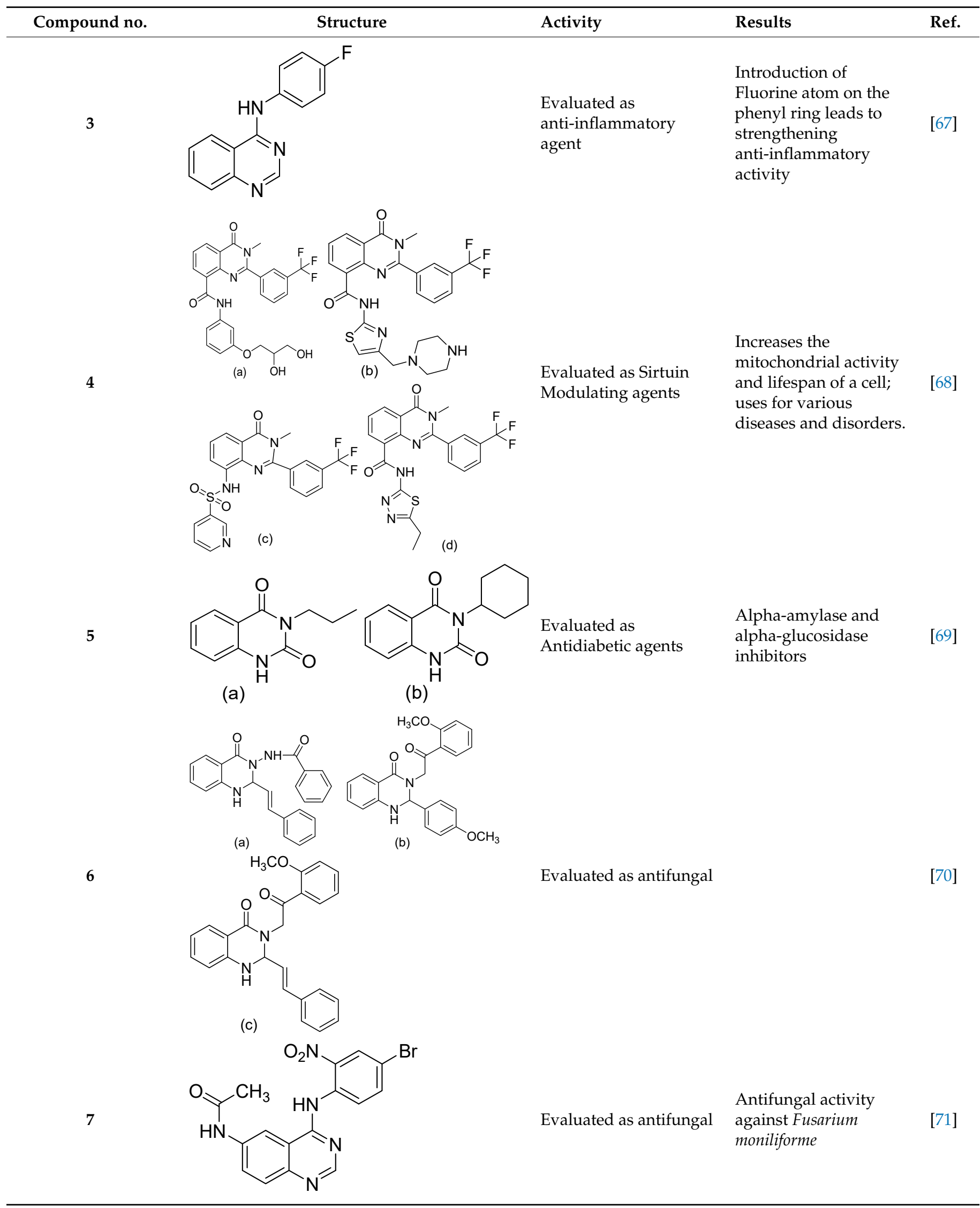


Table 7. Cont.

\begin{tabular}{|c|c|c|c|c|}
\hline Compound no. & Structure & Activity & Results & Ref. \\
\hline 8 & & Evaluated as antifungal & $\begin{array}{l}\text { Antifungal activity } \\
\text { against Candida albicans } \\
\text { and Aspergillus flavus }\end{array}$ & {$[72]$} \\
\hline 9 & & $\begin{array}{l}\text { Evaluated as } \\
\text { Antiparasite agents }\end{array}$ & $\begin{array}{l}\text { B-hematin formation } \\
\text { inhibitors }\end{array}$ & [73] \\
\hline 10 & & $\begin{array}{l}\text { Evaluated as } \\
\text { Antiparasite agents }\end{array}$ & $\begin{array}{l}\text { Most effective } \\
\text { derivatives against } P \text {. } \\
\text { falciparum } \\
\text { 3D7 and K1 strains }\end{array}$ & [74] \\
\hline 11 & & $\begin{array}{l}\text { Evaluated as } \\
\text { Antiparasite agents }\end{array}$ & $\begin{array}{l}\text { Showed activity on } \\
\text { promastigotes and } \\
\text { intracellular } \\
\text { amastigotes }\end{array}$ & {$[75]$} \\
\hline 12 & (b) & $\begin{array}{l}\text { Evaluated as } \\
\text { Antiplasmodium } \\
\text { agents }\end{array}$ & $\begin{array}{l}\mathrm{IC}_{50} \text { P. falci. } \mathrm{K} 1=0.94 \\
\mu \mathrm{M} \\
\mathrm{IC}_{50} \text { P. falci. } \mathrm{K} 1=0.9 \\
\mu \mathrm{M}\end{array}$ & [76] \\
\hline
\end{tabular}

\section{Quinazoline as Anti-Inflammatory Agents}

Stavytskyi et al. [66] synthesized substituted pyrrolo-quinazoline derivatives and tested their biological activity as an anti-inflammatory activity with reference to diclofenac. The synthesized compound as in Table 7, Compound 2, was found to be the most potent anti-inflammatory agent. Bansal et al. [67] designed and synthesized a novel class of 4-amino quinazoline derivatives and tested them for their anti-inflammatory activity. The 
synthesized compound $\mathrm{N}$-(4-fluorophenyl)quinazolin-4-amine as shown in Table 7, Compound 3 , was found to be the most potent compound which showed high anti-inflammatory activity. The synthesized compound was compared to standard drug indomethacin.

\section{Quinazoline as Sirtuin Modulating Agents}

Sirtuin modulating compounds were designed by Oalmann et al. [68] to increase the life of cells. Synthesized compounds N-(3-(2,3-dihydroxypropoxy)phenyl)-2-(3(trifluoromethyl)phenyl)-3,4-dihydro-3-methyl-4-oxoquinazoline-8-carboxamide (a) and their derivatives as in Table 7, Compound 4, were used for increasing the mitochondrial activity and preventing wide varieties of diseases and disorders.

\section{Quinazoline as Antidiabetic Agents}

A series with 3-substituted quinazoline-2,4 diones scaffolds was synthesized and evaluated for their biological activity as antidiabetic agents [69]. Synthesized compounds 3-propylquinazoline-2,4(1H,3H)-dione (a) and 3-cyclohexylquinazoline-2, $4(1 \mathrm{H}, 3 \mathrm{H})$-dione (b) as shown in Table 7, Compound 5, were found to have highly alpha-amylase and alphaglucosidase inhibitory activity in molecular docking studies artemia salina assay. These active compounds have shown unusual intermolecular interaction in the pocked site of the studied enzymes. Results showed that the synthesised compound is an inhibitor of the enzymes responsible for diabetic conditions like alpha-amylase and/or alpha-glucosidase.

\section{Quinazoline as Antifungal Agents}

Zhang et al. [70] synthesized a series of quinazolinone derivatives and evaluated them for their biological activity as antifungal agents. Synthesized compounds as shown in Table 7, Compound 6, were found to be highly potent as antifungal agents.

Nangare et al. [71] synthesized 4-(substituted aniline) quinazoline derivatives and evaluated them for their biological activity. Synthesized compound N-(4-(4-bromo-2nitrophenylamino)quinazolin-6-yl)acetamide as shown in Table 7, Compounds 7, had shown the strong antifungal activity against Fusarium moniliforme compared to the standard drug griseofulvin.

Agarwal et al. synthesized a series of quinazoline derivatives and evaluated them for their biological activity. The synthesized compound as shown in Table 7, Compounds 8, had shown strong antifungal activity compared to standard drug fluconazole [72].

\section{Quinazoline as Antiparasite Agents}

Mishra et al. prepared a series of quinazoline-chalcone hybrids and synthesized molecules were evaluated for their biological activity. The synthesized molecule (E)-1-(4-(2(trifluoromethyl)quinazoline-4-ylamino)phenyl)-3-(4-(trifluoromethyl)phenyl)prop-2-en-1one as shown in Table 7, Compound 9, was found to be a considerable inhibition of beta-hematin formation [73].

Tahghighi et al. prepared new synthetic derivatives of 1-(heteroaryl)-2-((5-nitroheteroaryl) methylene) hydrazine and evaluated their biological activity. The synthesized molecule as shown in Table 7, Compound 10, was most effective and had considerable inhibition of beta-hematin formation [74].

Martinez et al. synthesized a series of quinazoline 2,4,6-triamine derivatives and evaluated their biological activity. N6-(ferrocenmethyl)quinazoline-2,4,6-triamine as shown in Table 7, Compound 11, showed high activity on promastigotes and intracellular amastigotes with low cytotoxicity in mammalian cell [75]. Amrane et al. synthesized and evaluated antiplasmodial activity of 4-carboxamido and 4-alkoxy-2-trichloromethyl quinazoline derivatives. Synthesized compounds $N$-(2-(trichloromethyl)quinazoline-4-yl)-4fluorobenzamide (a), 4-chloro- $\mathrm{N}$-(2-(trichloromethyl)- quinazoline-4-yl)benzamide (b), 2(2-(trichloromethyl)quinazoline-4-yloxy)- $N, N$ - diethylethanamine (c) and 4-(2-(pyrrolidin1-yl)ethoxy)-2-(trichloromethyl)quinazoline (d) as shown in Table 7, Compound 12, were 
found to be highly effective as antiplasmodium agents against the multiresistant K1 P.falciparum strain, using doxorubicin and chloroquine as references [76].

\section{Conclusions}

Quinazoline is a structure of great interest in the area of pharmaceutical chemistry, featuring various drugs, clinical candidates and bioactive molecules. The focus of this review was on the potential biological activity of quinazoline derivatives. This review is additionally useful in providing information regarding the latest developments in quinazoline analogs having completely different pharmacological activity like antitumor, antimicrobial, antimalarial, antiviral and antidiabetic, etc. Diversified biological activities of quinazolinebased drugs comprise the role of substituents along with the position at quinazoline moiety, which gives an insight to understanding the drug and target relation. Therefore, critical and deep research for the various substituents of quinazoline is crucial for potential drug development. This review will provide substantial benefit to scientists for the design and synthesis of quinazoline moiety-based drugs for the safe treatment of various fetal diseases in future.

Author Contributions: This work was completed with the contributions of 4 authors. P.A. and R.K. designed and wrote the manuscript; M.S. performed final proof reading; N.M. carried out the final editing. All authors have read and agreed to the published version of the manuscript.

Funding: This research received no external funding.

Institutional Review Board Statement: Not applicable.

Informed Consent Statement: Not applicable.

Data Availability Statement: Not applicable.

Acknowledgments: The authors would like to extend heartfelt thanks to the Department of Basic Sciences, Galgotias University, Greater Noida and Neelima Mahato for providing valuable suggestions and moral support.

Conflicts of Interest: The authors declare no conflict of interest, financial or otherwise.

\section{References}

1. Wang, D.; Gao, F. Quinazoline derivatives: Synthesis and bioactivities. Chem. Cent. J. 2013, 7, 1-15. [CrossRef] [PubMed]

2. Connolly, D.J.; Cusack, D.; O'Sullivan, T.P.; Guiry, P.J. Synthesis of quinazolinones and quinazolines. Tetrahedron 2005, 61, 10153-10202. [CrossRef]

3. Meyer, J.F.; Wagner, E.C. The Niementowski reaction. The use of methyl anthranilate or isatoic anhydride with substituted amides or amidines in the formation of 3-substituted-4-keto-3,4-dihydroquinazolines. The course of the reaction. J. Org. Chem. 1943, 8, 239-252. [CrossRef]

4. Alam, M.J.; Alam, O.; Naim, M.J.; Alam, P. A review: Recent investigations on quinazoline scaffold. Int. J. Adv. Res. 2015, 3, 1656-1664.

5. Asif, M. Chemical Characteristics, Synthetic Methods, and Biological Potential of Quinazoline and Quinazolinone Derivatives. Int. J. Med. Chem. 2014, 2014, 395637. [CrossRef]

6. Hameed, A.; Al-Rashida, M.; Uroos, M.; Ali, S.A.; Arshia; Ishtiaq, M.; Khan, K.M. Quinazoline and quinazolinone as important medicinal scaffolds: A comparative patent review (2011-2016). Expert Opin. Ther. Pat. 2018, 28, 281-297. [CrossRef]

7. Sarker, S.D. Biological activity of magnolol: A review. Fitoterapia 1997, 68, 3-8.

8. Auti, P.S.; George, G.; Paul, A.T. Recent advances in the pharmacological diversification of quinazoline/quinazolinone hybrids. RSC Adv. 2020, 10, 41353-41392. [CrossRef]

9. Gupta, T.; Rohilla, A.; Pathak, A.; Akhtar, M.J.; Haider, M.R.; Yar, M.S. Current perspectives on quinazolines with potent biological activities: A review. Synth. Commun. 2018, 48, 1099-1127. [CrossRef]

10. Bisht, A.S.; Negi, J.S.; Sharma, D.K. Chemistry and activity of quinazoline moiety: A systematic review study. Int. J. Pharm. Chem. Anal. 2020, 7, 61-65. [CrossRef]

11. Sharif, M. Quinazolin-4(3H)-ones: A tangible synthesis protocol via an oxidative olefin bond cleavage using metal-catalyst free conditions. Appl. Sci. 2020, 10, 2815. [CrossRef]

12. Pao, W.; Miller, V.; Zakowski, M.; Doherty, J.; Politi, K.; Sarkaria, I.; Singh, B.; Heelan, R.; Rusch, V.; Fulton, L.; et al. EGF receptor gene mutations are common in lung cancers from "never smokers" and are associated with sensitivity of tumors to gefitinib and erlotinib. Proc. Natl. Acad. Sci. USA 2004, 101, 13306-13311. 
13. Stanaszek, W.F.; Kellerman, D.; Brogden, R.N.; Romankiewicz, J.A. Prazosin: A Review of its Pharmacological Properties and Heart Failure. Drugs 1983, 384, 339-384. [CrossRef]

14. Dowell, J.; Minna, J.D.; Kirkpatrick, P. Erlotinib hydrochloride. Nat. Rev. Drug Discov. 2005, 4, 13-14. [CrossRef]

15. Cherrier, L.; Nasar, A.; Goodlet, K.J.; Nailor, M.D.; Tokman, S.; Chou, S. Emergence of letermovir resistance in a lung transplant recipient with ganciclovir-resistant cytomegalovirus infection. Am. J. Transplant. 2018, 18, 3060-3064. [CrossRef]

16. Commander, H.; Whiteside, G.; Perry, C. Vandetanib: First global approval. Drugs 2011, 71, 1355-1365. [CrossRef]

17. Reckamp, K.L.; Giaccone, G.; Camidge, D.R.; Gadgeel, S.M.; Khuri, F.R.; Engelman, J.A.; Koczywas, M.; Rajan, A.; Campbell, A.K.; Gernhardt, D.; et al. A phase 2 trial of dacomitinib (PF-00299804), an oral, irreversible pan-HER (human epidermal growth factor receptor) inhibitor, in patients with advanced non-small cell lung cancer after failure of prior chemotherapy and erlotinib. Cancer 2014, 120, 1145-1154. [CrossRef]

18. Dungo, R.T.; Keating, G.M. Afatinib: First global approval. Drugs 2013, 73, 1503-1515. [CrossRef] [PubMed]

19. McKeage, K.; Plosker, G.L. Alfuzosin: A review of the therapeutic use of the prolonged-release formulation given once daily in the management of benign prostatic hyperplasia. Drugs 2002, 62, 633-653. [CrossRef] [PubMed]

20. Senkovich, O.; Schormann, N.; Chattopadhyay, D. Structures of dihydrofolate reductase-thymidylate synthase of trypanosoma cruzi in the folate-free state and in complex with two antifolate drugs, trimetrexate and methotrexate. Acta Crystallogr. Sect. D Biol. Crystallogr. 2009, 65, 704-716. [CrossRef] [PubMed]

21. Voigtlaender, M.; Schneider-Merck, T.; Trepel, M. Lapatinib. In Small Molecules in Oncology; Springer Nature: Basingstoke, UK, 2018; pp. 19-44. [CrossRef]

22. Marsh, C.C.; Schuna, A.A.; Sundstrom, W.R. A Review of Selected Investigational Nonsteroidal Antiinflammatory Drugs of the 1980s. Pharmacother. J. Hum. Pharmacol. Drug Ther. 1986, 6, 10-25. [CrossRef] [PubMed]

23. Guillon, R.; Pagniez, F.; Picot, C.; Hédou, D.; Tonnerre, A.; Chosson, E.; Duflos, M.; Besson, T.; Logé, C.; Le Pape, P. Discovery of a novel broad-spectrum antifungal agent derived from albaconazole. ACS Med. Chem. Lett. 2013, 4, 288-292. [CrossRef] [PubMed]

24. Hammer, H.; Bader, B.M.; Ehnert, C.; Bundgaard, C.; Bunch, L.; Hoestgaard-Jensen, K.; Schroeder, O.H.U.; Bastlund, J.F.; Gramowski-Voß, A.; Jensen, A.A. A multifaceted GABAA receptor modulator: Functional properties and mechanism of action of the sedative-hypnotic and recreational drug methaqualone (Quaalude). Mol. Pharmacol. 2015, 88, 401-420. [CrossRef]

25. Liu, Y.; Wu, W.; Hong, W.; Sun, X.; Wu, J.; Huang, Q. Raltitrexed-based chemotherapy for advanced colorectal cancer. Clin. Res. Hepatol. Gastroenterol. 2014, 38, 219-225. [CrossRef] [PubMed]

26. Ewes, W.A.; Elmorsy, M.A.; El-Messery, S.M.; Nasr, M.N.A. Synthesis, biological evaluation and molecular modeling study of [1,2,4]-Triazolo[4,3-c]quinazolines: New class of EGFR-TK inhibitors. Bioorg. Med. Chem. 2020, 28, 115373. [CrossRef] [PubMed]

27. Allam, H.A.; Aly, E.E.; Farouk, A.K.B.A.W.; El Kerdawy, A.M.; Rashwan, E.; Abbass, S.E.S. Design and Synthesis of some new 2,4,6-trisubstituted quinazoline EGFR inhibitors as targeted anticancer agents. Bioorg. Chem. 2020, 98, 103726. [CrossRef] [PubMed]

28. Das, D.; Xie, L.; Wang, J.; Shi, J.; Hong, J. In vivo efficacy studies of novel quinazoline derivatives as irreversible dual EGFR/HER2 inhibitors, in lung cancer xenografts (NCI-H1975) mice models. Bioorg. Chem. 2020, 99, 103790. [CrossRef]

29. Lin, S.Y.; Chang, C.F.; Coumar, M.S.; Chen, P.Y.; Kuo, F.M.; Chen, C.H.; Li, M.C.; Lin, W.H.; Kuo, P.C.; Wang, S.Y.; et al. Drug-like property optimization: Discovery of orally bioavailable quinazoline-based multi-targeted kinase inhibitors. Bioorg. Chem. 2020, 98, 103689. [CrossRef]

30. El-Azab, A.S.; Abdel-Aziz, A.A.M.; Bua, S.; Nocentini, A.; AlSaif, N.A.; Alanazi, M.M.; El-Gendy, M.A.; Ahmed, H.E.; Supuran, C.T. S-substituted 2-mercaptoquinazolin-4(3H)-one and 4-ethylbenzensulfonamides act as potent and selective human carbonic anhydrase IX and XII inhibitors. J. Enzyme Inhib. Med. Chem. 2020, 35, 733-743. [CrossRef]

31. Rahmannejadi, N.; Yavari, I.; Khabnadideh, S. Synthesis and antitumor activities of novel bis-quinazolin-4(3H)-ones. J. Heterocycl Chem. 2020, 57, 978-982. [CrossRef]

32. Khodair, A.I.; Alsafi, M.A.; Nafie, M.S. Synthesis, molecular modeling and anti-cancer evaluation of a series of quinazoline derivatives. Carbohydr. Res. 2019, 486, 107832. [CrossRef]

33. Le, Y.; Gan, Y.; Fu, Y.; Liu, J.; Li, W.; Zou, X.; Zhou, Z.; Wang, Z.; Ouyang, G.; Yan, L. Design, synthesis and in vitro biological evaluation of quinazolinone derivatives as EGFR inhibitors for antitumor treatment. J. Enzym. Inhib. Med. Chem. 2020, 35, 555-564. [CrossRef]

34. Li, W.; Chen, S.Y.; Hu, W.N.; Zhu, M.; Liu, J.M.; Fu, Y.H.; Wang, Z.C.; OuYang, G.P. Design, synthesis, and biological evaluation of quinazoline derivatives containing piperazine moieties as antitumor agents. J. Chem. Res. 2020, 44, 536-542. [CrossRef]

35. Alkahtani, H.M.; Abdalla, A.N.; Obaidullah, A.J.; Alanazi, M.M.; Almehizia, A.A.; Alanazi, M.G.; Ahmed, A.Y.; Alwassil, O.I.; Darwish, H.W.; Alaa, A.M.; et al. Synthesis, cytotoxic evaluation, and molecular docking studies of novel quinazoline derivatives with benzenesulfonamide and anilide tails: Dual inhibitors of EGFR/HER2. Bioorg. Chem. 2020, 95, 103461. [CrossRef] [PubMed]

36. Abuelizz, H.A.; Marzouk, M.; Ghabbour, H.; Al-Salahi, R. Synthesis and anticancer activity of new quinazoline derivatives. Saudi Pharm. J. 2017, 25, 1047-1054. [CrossRef] [PubMed]

37. Vu, T.K. New Quinazolinone Derivatives: Sythesis and in vitro Cytotoxic Activity. Vietnam J. Sci. Technol. 2020, 58, 12. [CrossRef]

38. Zhang, Y.; Zhang, Y.; Liu, J.; Chen, L.; Zhao, L.; Li, B.; Wang, W. Synthesis and in vitro biological evaluation of novel quinazoline derivatives. Bioorg. Med. Chem. Lett. 2017, 27, 1584-1587. [CrossRef]

39. Srinivas, S.; Aparna, V. Design, synthesis, biological evaluation and molecular docking studies of novel quinazoline derivatives as GSK-3 $\beta$ inhibitors. World J. Pharm. Pharm. Sci. 2013, 2, 5842-5851. 
40. Wallace, E.; Lyssikatos, J.; Topalav, G.; Buckmelter, A.; Zhao, Q. Qinazoline analogs as receptors tyrosine kinase inhibitors. U.S. Patent 9,676,791, 13 June 2017.

41. Vishwakarma, R.A.; Bharate, S.B.; Bhushan, S.; Yadav, R.R.; Guru, S.K.; Joshi, P. 6-Aryl-4-phenylamino-quinazoline Analogs as Phosphoinositide-3-kinase Inhibitors. U.S. Patent 10,202,374, 12 February 2019.

42. Golden, D.; Gb, M.; Hogan, P.J.; Gb, M.; Michael, D.; Martin, G. Chemical process for the Synthesis of 4-(4-bromo-2-fluoroanilino)6-methoxy-7-(1-methylpiperidin-4-ylmethoxy)quinazoline. United States Patent. Vol. 2. U.S. Patent 10,344,015, 9 July 2019.

43. Lindmark, B.; Ooi, L. Combination Therapy Comprising Varlitinib and an Anticancer Agent. Vol. 2. Singapore (SG). U.S. Patent 10,357,494, 23 July 2019.

44. Ci, U.S.; Sui, I.; Cai, X.; Cn, J.; Jiang, Y.; Cn, J. 1-(Arylmethyl)quinazoline-2,4(1H,3H)-diones as PARP Inhibitors and the Use Thereof. Vol. 2. U.S. Patent 10,316,027, 11 June 2019.

45. Wallace, E.; Tapalov, G.; Lyssikatose, J.; Buckmelter, A.; Qian, Z. Quinazoline Analogs as Receptor Tyrosine Kinase Inhibitors. Vol. 2. U.S. Patent 9,676,791, 13 June 2017.

46. Ghorab, M.M.; Abdel-Kader, M.S.; Alqahtani, A.S.; Soliman, A.M. Synthesis of some quinazolinones inspired from the natural alkaloid L-norephedrine as EGFR inhibitors and radiosensitizers. J. Enzym. Inhib. Med. Chem. 2021, 36, 218-237. [CrossRef]

47. Wang, M.; Zhang, G.; Wang, Y.; Wang, J.; Zhu, M.; Cen, S.; Wang, Y. Design, synthesis and anti-influenza A virus activity of novel 2,4-disubstituted quinazoline derivatives. Bioorg. Med. Chem. Lett. 2020, 30, 127143. [CrossRef]

48. Rothan, H.; Faraj, F.L.; Teoh, T.C.; Yusof, R. Novel Quinazoline derivatives inhibited HCV Serine protease and viral replication in Huh-7 cells. Nov Quinazoline Deriv Inhib HCV Serine protease viral replication Huh-7 cells. bioRxiv 2019, 671313. [CrossRef]

49. Fan, Z.; Shi, J.; Bao, X. Synthesis and antimicrobial evaluation of novel 1,2,4-triazole thioether derivatives bearing a quinazoline moiety. Mol. Divers. 2018, 22, 657-667. [CrossRef]

50. Fröhlich, T.; Reiter, C.; Ibrahim, M.M.; Beutel, J.; Hutterer, C.; Zeitträger, I.; Bahsi, H.; Leidenberger, M.; Friedrich, O.; Kappes, B.; et al. Synthesis of Novel Hybrids of Quinazoline and Artemisinin with High Activities against Plasmodium falciparum, Human Cytomegalovirus, and Leukemia Cells. ACS Omega 2017, 2, 2422-2431. [CrossRef]

51. Xie, D.; Shi, J.; Zhang, A.; Lei, Z.; Zu, G.; Fu, Y.; Gan, X.; Yin, L.; Song, B.; Hu, D. Syntheses, antiviral activities and induced resistance mechanisms of novel quinazoline derivatives containing a dithioacetal moiety. Bioorg. Chem. 2018, 80, 433-443. [CrossRef]

52. Zhang, G.P.; Pan, J.K.; Zhang, J.; Wu, Z.X.; Liu, D.Y.; Zhao, L. Design, Synthesis, Antiviral Activities of Novel Phosphonate Derivatives Containing Quinazoline Based on Chalone Motif. J. Heterocycl. Chem. 2017, 54, 2548-2555. [CrossRef]

53. Heil, M.L.; Cosford, N.D.; Ardecky, R.; Zou, J. Quinazolinone analogs and use of Quinazolinone analogs for treating or preventing certain Viral infection. U.S. Patent 10,611,733, 21 March 2017.

54. Misra, A.; Dwivedi, J.; Shukla, S.; Kishore, D.; Sharma, S. Bacterial cell leakage potential of newly synthesized quinazoline derivatives of 1,5-benzodiazepines analogue. J. Heterocycl. Chem. 2020, 57, 1545-1558. [CrossRef]

55. Sunil Kumar, A.; Kudva, J.; Lahtinen, M.; Peuronen, A.; Sadashiva, R.; Naral, D. Synthesis, characterization, crystal structures and biological screening of 4-amino quinazoline sulfonamide derivatives. J. Mol. Struct. 2019, 1190, 29-36. [CrossRef]

56. Peter, J.; Mark, S.; Flanigan, D.L.; Helen, W.; George, H.; John, S. Disubstituted Quinazoline-2,4 Diamines and Uses Thereof. Vol. 1. U.S. Patent 10,323,007, 18 June 2019.

57. Chang, M.; Mobashery, S.; Bouley, R. Quinazolinone Antibiotics. Vol. 2. U.S. Patent 10,329,262, 25 June 2019.

58. Jadhavar, P.S.; Patel, K.I.; Dhameliya, T.M.; Saha, N.; Vaja, M.D.; Krishna, V.S.; Sriram, D.; Chakraborti, A.K. Benzimidazoquinazolines as new potent anti-TB chemotypes: Design, synthesis, and biological evaluation. Bioorg. Chem. 2020, 99, 103774. [CrossRef] [PubMed]

59. Gawad, J.; Bonde, C. Design, synthesis and biological evaluation of novel 6-(trifluoromethyl)-N-(4-oxothiazolidin-3-yl)quinazoline2-carboxamide derivatives as a potential DprE1 inhibitors. J. Mol. Struct. 2020, 1217, 128394. [CrossRef]

60. Lupien, A.; Foo, C.S.Y.; Savina, S.; Vocat, A.; Piton, J.; Monakhova, N.; Benjak, A.; Lamprecht, D.A.; Steyn, A.J.; Pethe, K.; et al. New 2-Ethylthio-4-methylaminoquinazoline derivatives inhibiting two subunits of cytochrome bc1 in Mycobacterium tuberculosis. PLoS Pathog. 2020, 16, e1008270. [CrossRef] [PubMed]

61. Al-Salahi, R.; Taie, H.A.A.; Bakheit, A.H.; Marzouk, M.; Almehizia, A.A.; Herqash, R.; Abuelizz, H.A. Antioxidant activities and molecular docking of 2-thioxobenzo[g]quinazoline derivatives. Pharmacol. Rep. 2019, 71, 695-700. [CrossRef]

62. Almehizia, A.A.; Abuelizz, H.A.; Taie, H.A.A.; ElHassane, A.; Marzouk, M.; Al-Salahi, R. Investigation the antioxidant activity of benzo[g]triazoloquinazolines correlated with a DFT study. Saudi Pharm. J. 2019, 27, 133-137. [CrossRef]

63. Dixit, A.; Pathak, D.; Sharma, G.K. Synthesis, antibacterial and antioxidant activity of novel 12-(N-arylmethaniminyl)indolo[1,2c]quinazolines. Marmara Pharm. J. 2019, 23, 584-595. [CrossRef]

64. Hricoviniova, J.; Hricoviniova, Z.; Kozica, K. Antioxidant, Cytotoxic, Genotoxic, and DNA Protective Potential of 2,3-Substituted Quinazolinones: Structure-Activity Relationship Study. Int. J. Mol. Sci. 2021, 22, 610. [CrossRef]

65. Jain, R.K.; Kashaw, V. Design, synthesis and evaluation of novel 2,3-disubstituted-4-(3H) quinazolinone derivatives. Asian J. Pharm. Pharmacol. 2018, 4, 644-656. [CrossRef]

66. Stavytskyi, V.; Voskoboinik, O.; Kazunin, I.; Nosulenko, I.; Shishkina, S.; Kovalenko, S. Substituted pyrrolo[1,2-a][1,2,4]triazolo$([1,2,4]$ triazino-)[c]quinazoline-4A(5a)-propanoic acids: Synthesis, spectral characteristics and anti-inflammatory activity. Vopr. Khimii I Khimicheskoi Tekhnologii. 2020, 2020, 61-70. 
67. Bansal, R. Design and Synthesis of Some Quinazoline Derivatives as Anti-Inflammatory Agents. Int. J. Engg. Tech. Sci. and Res. 2017, 4, 61-62.

68. Oalmann, C.; Perni, R.B.; Us, M.A.; White, B. Quinazolinone, Quinolone Related Analogs as Sirtuin Modulators. Vol. 2. U.S. Patent 10,329,262, 3 May 2016.

69. Santos-Ballardo, L.; García-Páez, F.; Picos-Corrales, L.A.; Ochoa-Terán, A.; Bastidas, P.; Calderón-Zamora, L.; Rendón-Maldonado, G.; Osuna-Martínez, U.; Sarmiento-Sánchez, J.I. Synthesis, biological evaluation and molecular docking of 3-substituted quinazoline-2,4(1H, 3H)-diones. J. Chem. Sci. 2020, 132, 100. [CrossRef]

70. Zhang, J.; Liu, J.; Ma, Y.; Ren, D.; Cheng, P.; Zhao, J.; Zhang, F.; Yao, Y. One-pot synthesis and antifungal activity against plant pathogens of quinazolinone derivatives containing an amide moiety. Bioorg. Med. Chem. Lett. 2016, 26, 2273-2277. [CrossRef]

71. Nangare, A.; Randive, D.; Barkade, G. Synthesis and Biological evaluation of Novel Quinazoline derivatives as Anticancer, Antibacterial and Antifungal agents. Bull. Env. Pharmacol. Life Sci. 2021, 10, 179-190.

72. Agrawal, G.; Khan, N.; Dwivedi, S.; Patel, R.; Singh, G. Synthesis, Characterization and Anti-Microbial Evaluation of a Series of Quinazoline analogs. J. Adv. Sci. Res. 2021, 12, 123-130.

73. Mishra, M.; Mishra, V.K.; Kashaw, V.; Agrawal, R.K.; Kashaw, S.K. Novel Quinazoline Chalcone Hybrids as Antiplasmodium Agents: Synthesis, Biological Evaluation and Molecular Docking. J. Adv. Sci. Res. 2020, 11, 85-99.

74. Tahghighi, A.; Mehrizi, A.; Zakeri, S. In vitro anti-plasmodial activity of new synthetic derivatives of 1-(heteroaryl)-2-((5nitroheteroaryl)methylene) hydrazine. Asian Pac. J. Trop. Med. 2021, 14, 128-138.

75. Mendoza-Martínez, C.; Galindo-Sevilla, N.; Correa-Basurto, J.; Ugalde-Saldivar, V.M.; Rodriguez-Delgado, R.G.; HernándezPineda, J.; Padierna-Mota, C.; Flores-Alamo, M.; Hernández-Luis, F. Antileishmanial activity of quinazoline derivatives: Synthesis, docking screens, molecular dynamic simulations and electrochemical studies. Eur. J. Med. Chem. 2015, 92, 314-331. [CrossRef] [PubMed]

76. Amrane, D.; Gellis, A.; Hutter, S.; Prieri, M.; Verhaeghe, P.; Azas, N.; Vanelle, P.; Primas, N. Synthesis and Antiplasmodial Evaluation of 4-Carboxamido- and 4-Alkoxy-2-Trichloromethyl Quinazolines. Molecules 2020, 25, 3929. [CrossRef] 